\title{
Application of medical gases in the field of neurobiology
}

\author{
Wenwu Liu', Nikan Khatibi², Aishwarya Sridharan² and John H Zhang ${ }^{2,3^{*}}$
}

\begin{abstract}
Medical gases are pharmaceutical molecules which offer solutions to a wide array of medical needs. This can range from use in burn and stroke victims to hypoxia therapy in children. More specifically however, gases such as oxygen, helium, xenon, and hydrogen have recently come under increased exploration for their potential theraputic use with various brain disease states including hypoxia-ischemia, cerebral hemorrhages, and traumatic brain injuries. As a result, this article will review the various advances in medical gas research and discuss the potential therapeutic applications and mechanisms with regards to the field of neurobiology.
\end{abstract}

Keywords: Medical gases, Gas pre-conditioning, oxygen therapy, hydrogen therapy

\section{Introduction}

Medical gases, pharmaceutical molecules which offer solutions to a wide array of medical needs, range from traditional gases (oxygen and nitrous oxide) to gases like nitric oxide, carbon monoxide, and hydrogen sulfide-all of which have been recently shown to behave as biological messenger molecules [1]. Some gases, such as helium and xenon, have even been shown to be neuroprotective following various brain injuries such as acute ischemic stroke, perinatal hypoxia-ischemia, traumatic brain injury, and cardiopulmonary bypass-induced neurologic and neurocognitive dysfunctions [2-4]. In this paper, we will briefly introduce and review the history of oxygen, helium, xenon, and hydrogen gas, and discuss the various therapeutic mechanisms that have been proposed in the current literature.

\section{Oxygen}

Air is composed of $78 \%$ nitrogen, $21 \%$ oxygen, and less than $1 \%$ of other gases. If more oxygen is needed, hyperoxia can be induced to increase the fraction of inhaled oxygen, and therefore the diffusion of oxygen through blood. This can be achieved under normobaric, or hyperbaric conditions. Normobaric hyperoxia (normobaric oxygen, NBO) is applied via a wide variety of masks that

\footnotetext{
* Correspondence: johnzhang3910@yahoo.com

²Department of Anesthesiology, Loma Linda Medical Center, Loma Linda, California, USA

Full list of author information is available at the end of the article
}

allow delivery of inspired oxygen ranging from $24 \%$ to $90 \%$. Higher concentrations can be delivered via masks with reservoirs, tightly fitting continuous positive airway pressure-type masks, or through mechanical ventilation. In contrast, under hyperbaric conditions, one can breathe $100 \%$ oxygen (small chamber for single occupant), or breathe compressed air and 100\% oxygen intermittently through a mask or hood (large multiplace hyperbaric chamber).

\section{Mechanism underlying the theraputic effects of hyperoxia}

Hyperoxia is an attractive therapeutic option because it has several properties of an 'ideal' protective agent. Unlike most pharmaceutical drugs, oxygen is simple to administer, easily diffuses to target tissues, is well tolerated, can be delivered in 100\% concentrations without significant side effects, and can theoretically be combined with other treatments.

To date, the mechanisms underlying the therapeutic effects of hyperoxia are quite complex, with a variety of mechanisms under investigation (Figure 1). According to some studies, hyperoxia has been shown to modulate aerobic metabolism, and to regulate blood flow via vasoreactivity. At the same time, the changes in aerobic metabolism can also regulate blood flow in the body. Therefore, although described independently, the mechanisms underlying the therapeutic potential of hyperoxia are vast and influence each other, to a certain degree.
C Biomed Central

C 2011 Liu et al; licensee BioMed Central Ltd. This is an Open Access article distributed under the terms of the Creative Commons Attribution License (http://creativecommons.org/licenses/by/2.0), which permits unrestricted use, distribution, and reproduction in any medium, provided the original work is properly cited. 


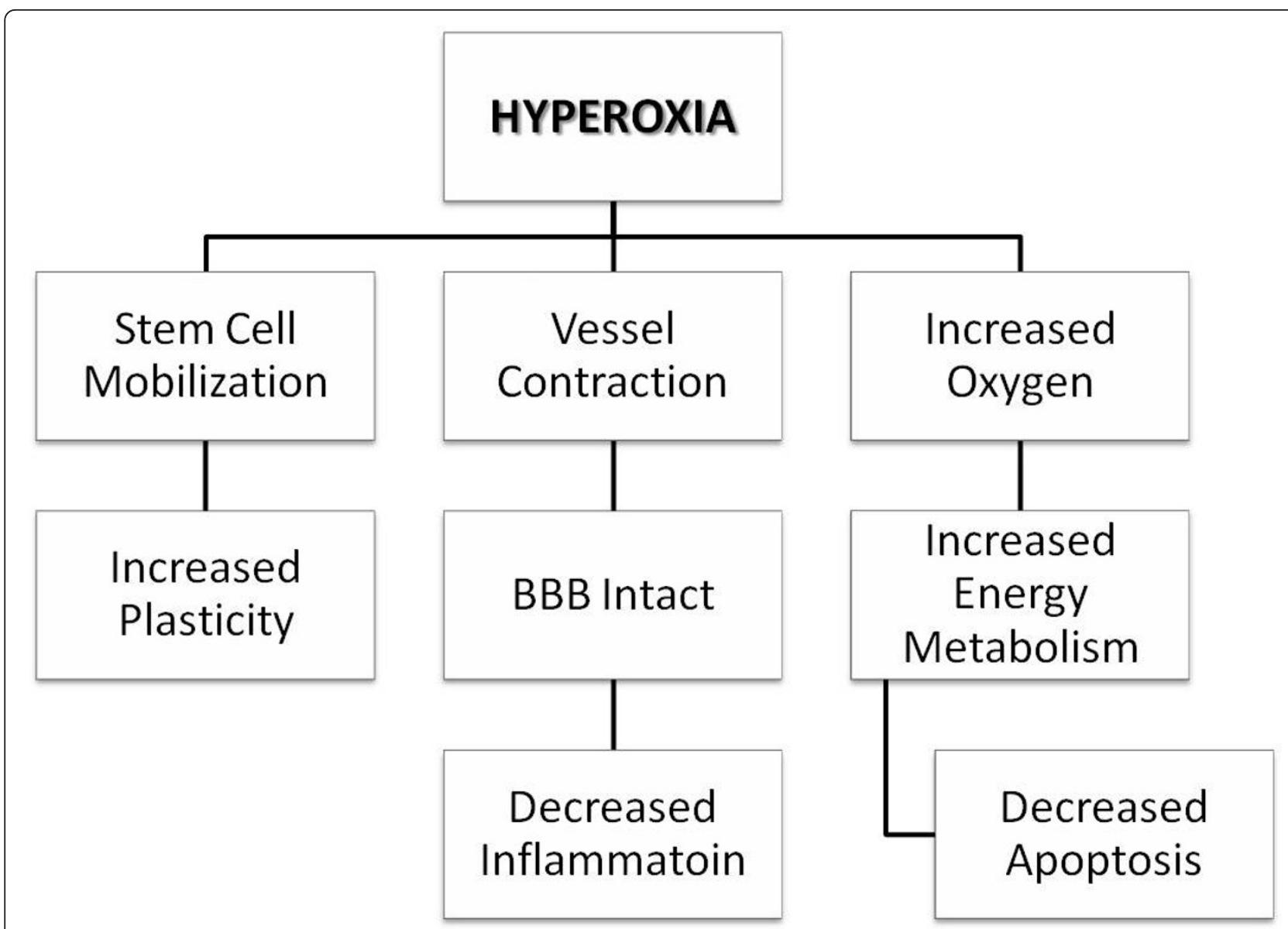

Figure 1 Mechanisms underlying the protective effects of hyperoxia. The mechanisms underlying the therapeutic effects of hyperoxia are quite complex, with a variety of mechanisms ranging from stem cell mobilization to enhancement of the neuroplasticity process under investigation.

\section{Hyperoxia increases oxygen supply}

Delivery of oxygen to tissues depends on adequate ventilation, gas exchange, circulatory distribution, and the partial pressure of inhaled oxygen. At normal sea levels, the partial pressure of oxygen $\left(\mathrm{pO}_{2}\right)$ of inspired air is around $160 \mathrm{mmHg}$. This progressively drops as oxygen is carried further in the body. In other words, the first drop occurs in the lungs because of water vapor and diffusion, then in the vasculature leaving the alveolar capillaries, where the $\mathrm{pO}_{2}$ is around $104 \mathrm{mmHg}$, as it moves towards organs and tissues for perfusion. The diffusion distance of oxygen in a tissue is approximately 100 200 $\mu \mathrm{m}$ and an oxygen partial pressure of almost zero has been reported at about $100 \mu \mathrm{m}$ from blood vessels $[5,6]$.

It is also important to recall that the hemoglobin dissociation curve shows hemoglobin to be $100 \%$ saturated when the partial pressure of arterial oxygen $\left(\mathrm{PaO}_{2}\right)$ is approximately $80 \mathrm{mmHg}$. Under conditions of complete saturation, as is the case with $100 \%$ oxygen administration under normobaric conditions, each gram of healthy hemoglobin contains $1.39 \mathrm{ml}$ of oxygen, which accounts for only a small increase in the oxygen content of arterial blood.

Additionally, the amount of oxygen physically dissolved in the blood also increases proportionally with the partial pressure of ambient oxygen. The amount of oxygen dissolved in plasma is negligible under physiological oxygen tensions, but normobaric hyperoxia may increase the amount of dissolved oxygen by approximately $0.5 \sim 1 \%$ while hyperbaric oxygen can increase it considerably more. Inhalation of $100 \%$ oxygen at normal atmospheric pressure yields a 5-to 7-fold increase in arterial blood oxygen tension, which can only satisfy one-third of the oxygen requirements of resting tissue due to the low plasma solubility of oxygen. However, under hyperbaric conditions (such as 3 atmosphere absolute), the arterial blood oxygen tension may reach values close to $2,000 \mathrm{~mm} \mathrm{Hg}$, resulting in levels of plasma dissolved oxygen (about 6\%) that can meet the average requirements of resting tissues, without a contribution from oxygen bound to hemoglobin [7]. 
The marked increase in oxygen tension gradient from the capillary blood to tissue cells is a key mechanism by which hyperoxygenation of arterial blood can improve effective cellular oxygenation, even at a low rate of tissue perfusion. The increased oxygen supply during normobaric hyperoxia or hyperbaric hyperoxia contributes to bactericidal effects within the tissue. Anaerobic microorganisms, in particular, do not have defense mechanisms against the increased production of reactive oxygen species (ROS) in hyperoxic environments $[8,9]$.

\section{Hyperoxia on the hemodynamics}

In healthy animals and humans, oxygen inhalation can increase the total peripheral vascular resistance, secondary to systemic peripheral vasoconstriction. This results in a temporary increase in blood pressure, which is rapidly counterbalanced by a decrease in heart rate and cardiac output [10].

The brain has an extremely high metabolic rate; its oxygen demand exceeds that of all organs except the heart. Despite its relative small size ( $2 \%$ of total body weight), the brain receives approximately $20 \%$ of the cardiac output, and accounts for about $20 \%$ of the body's oxygen consumption. Over a normal physiological range of $\mathrm{PaO}_{2}(7 \pm 13.33 \mathrm{kPa})$, there is little change in cerebral blood flow (CBF). Changes in oxygen tension are a potent stimulus for arterial dilatation/contraction. Rodent [11] and human [12] studies have shown that hyperoxia induces beneficial hemodynamic effects.

Kety and Schmidt originally described a reduction of $13 \%$ in CBF, and a moderate increase in the cerebrovascular resistance of young male volunteers inhaling 85$100 \%$ oxygen [13]. Omae and colleagues confirmed that increases in $\mathrm{PaO}_{2}$ led to a significant reduction in the flow velocity within the middle cerebral artery. However, when oxygen was increased from $100 \%$ at 1 ATA to $100 \%$ oxygen at 2 ATA, there were no further reductions in flow velocity within the middle cerebral artery [14].

Additionally, the increase in the mean partial pressure of oxygen in the tissues by hyperoxia has significant heterogeneities. The increase in heterogeneity is speculated to be a result of the redistribution of blood flow, with vasoconstriction in some areas and shunting in others. Under pathological conditions, hyperoxia may lead to the opening of collaterals, or a 'reverse steal' effect through diversion of blood from non-injured tissues into injured tissues. The unique combination of hyperoxia-induced vasoconstriction and high arterial blood oxygen decreases the vasogenic component of increased tissue hydrostatic pressure while preserving a high blood-to-tissue oxygen partial pressure gradient.

In the past, various mediators and mechanisms, such as increased effects of serotonin, nitric oxide synthase inhibition, inhibition of endothelial prostaglandin synthesis and increased leukotriene production, have been shown to play a key role in cerebral oxygen vasoreactivity [15].

\section{Hyperoxia on energy metabolism}

The downstream molecular effects of improved oxygenation are largely hypothetical. Increased aerobic metabolism leads to an increased production of ATP during aerobic cellular respiration in the mitochondria.

This hypothesis is indirectly supported by measurements of lactate and pyruvate in the cerebrospinal fluid (CSF). Daugherty et al investigated the oxygen consumption and mitochondrial redox potential during oxygen therapy [16]. Results showed that hyperbaric oxygen (HBO) not only induced an increase in oxygen consumption in both injured and sham-injured animals, but also enhanced the recovery of mitochondrial function [16]. Rockswold et al also revealed that $\mathrm{HBO}$ may improve aerobic metabolism by increasing the cerebral metabolic rate of oxygen and decreasing the lactate levels in CSF [17]. A more recent study revealed significantly greater improvements in the cerebral blood flow, cerebral metabolic rate of oxygen, microdialysate lactate, and the lactate/pyruvate $(\mathrm{L} / \mathrm{P})$ ratio when the partial pressure of oxygen in the brain tissue was $\geq 200 \mathrm{~mm} \mathrm{Hg}$, which is achieved during $\mathrm{HBO}$ or normobaric oxygen treatment [18]. Additionally, they found the effect of HBO on treatment to be more robust than that of normobaric oxygen on oxidative cerebral metabolism [18]. Normobaric hyperoxia, which increases brain tissue oxygenation, has a variable effect on the lactate and lactate/pyruvate ratio in addition to having a preferential metabolic benefit [19]. By using early high resolution positron emission tomography, Lou et al showed that exposure of the ischemic brain to $\mathrm{HBO}$ can partially reverse the downward trend for glucose utilization in the ischemic core, which might explain the reported benefits of early $\mathrm{HBO}$ therapy on permanent cerebral ischemia [20].

\section{Hyperoxia on the inflammatory process}

$\mathrm{HBO}$ contributes to curtail inflammation through various anti-inflammatory mechanisms. Following injury, white blood cells can migrate to the injured site producing inflammation. This is characterized by upregulation of adhesion molecules and chemokines, which play important roles in inflammatory migration. In this regard, $\mathrm{HBO}$ has been shown to decrease the rolling and adhesion mechanisms of polymorphonuclear leukocytes (PMNL), mediated by $\beta 2$ integrin glycoproteins CD11/ CD18, in the microcirculation following injuries [21]. Hyperoxia also reduces the expression of the endothelial adhesion molecules E-selectin [22] and intracellular adhesion molecule-1 (ICAM-1) [23]. Additionally, hyperoxia induces the production of endothelial NO synthase (eNOS) which synthesizes nitric oxide (NO), a protein which contributes to the reduction of PMNL adhesion to 
human vascular endothelial cell [24,25]. Additionally, hyperoxia reduces the mRNA and protein levels of cyclooxygenase-2 (COX-2), a key enzyme of prostanoid metabolism which also has a predominantly negative effect on inflammation induced by experimental ischemia [26]. By using directed microarray analysis, Rink et al showed that supplemental oxygen limited leukocyte accumulation at the infarct site by attenuation of the stroke-inducible pro-inflammatory chemokine response [27].

\section{Hyperoxia on delayed cell death}

Previous research suggests that hyperoxia can inhibit apoptosis. In several studies, HBO-treated rodents had reduced apoptotic markers in neonatal hypoxia-ischemia, as well as focal and global cerebral ischemia models $[28,29]$. Additionally, Henninger et al [30] reported that normobaric oxygen treatment reduces apoptotic cell death in the ischemic hemisphere.

\section{Hyperoxia on vascular permeability}

Hyperoxia has also been shown to preserve the integrity of the blood-brain barrier (BBB) by reducing vascular permeability. Previous studies have shown that early intra-ischemic $\mathrm{HBO}$ treatment reduces the $\mathrm{BBB}$ disruption, hemorrhagic transformation, and subsequent mortality following focal cerebral ischemia [31,32]. Additionally, Sun et al used MRI to demonstrate that hyperbaric and normboaric oxygen treatments significantly reduce post-ischemic BBB permeability on postcontrast $\mathrm{T} 1$-weighted images in middle cerebral artery occlusion (MCAO) models [33].

Protection of the BBB by hyperoxia may be related to the reduction of matrix metalloproteinases (MMPs), which are predominant enzymes involved in the degradation of the components of the vascular basement membrane [34]. This effect may be mediated by NADPH oxidase [35] and/or hypoxia-inducible factor (HIF) [36] because reduction of NADPH oxidase after hyperoxia results in the decreased production of ROS, which play an important role in the activation of MMPs [37]. Moreover, HIF-1 has been implicated in the control of MMPs, including MMP-2 (gelatinase A) and MMP-9 (gelatinase B), which can degrade components of the extracellular matrix surrounding cerebral blood vessels [38].

\section{Hyperoxia on the plasticity process}

Following an initial cerebral injury, post-acute brain plasticity is critical for determination of functional brain improvement. The absence of neuroanatomical plasticity following cerebral injury is attributable to several factors, including glial scars, lack of neurotrophins, and growth inhibitory molecules. Neurite outgrowth inhibitor (NogoA), one of the most powerful growth inhibitors, is related to the plasticity of the central nervous system. Zhou et al revealed that $\mathrm{HBO}$ significantly decreased the levels of
Nogo-A, and Ras homolog gene family, member A (RhoA) during an ischemic injury in the cortex, which might partially contribute to the improvement of neurological function [39]. Garcia et al also showed that a transient acute hyperoxia stimulus, whether caused by breathing $\mathrm{HBO}$ or reoxygenation following hypoxia, is a powerful stimulant for orthodromic activity and neural plasticity in the CA1 hippocampus [40]. Additionally, hyperbaric oxygen treatment promotes neural plasticity by increasing Map-2 expression and decreaseing GFAP [41].

\section{Neuroclinical application of oxygen therapy}

Oxygen therapy remains a cornerstone of modern medical practice and many of its physiological actions have already been elucidated. With regards to the field of neurology, oxygen therapy has been studied in stroke and traumatic brain injury (TBI) cases due to the prevalence of both diseases.

\section{Normobaric hyperoxia on traumatic brain injury}

In 1998, Thiagarajan et al applied hyperoxia in TBI patients undergoing hyperventilation. Their results showed that increases in the $\mathrm{PaO}_{2}$ above normal levels could offset the deleterious effects of hyperventilation on jugular bulb oxygen saturation and arteriovenous oxygenation content difference in patients with head injuries [42]. To this date, the most cited study was conducted by Tolias et al [43]. This was a prospective study where 52 patients with severe TBI were treated with a $\mathrm{FiO}_{2}$ (fraction of inspired oxygen) of $100 \%$ for $24 \mathrm{~h}$ within $6 \mathrm{~h}$ of admission. When compared with 112 patients in a historical cohort study, patients treated with $100 \% \mathrm{FiO}_{2}$ had increased glucose levels and decreased glutamate and lactate levels. Microdialysis also showed reductions in the lactate/glucose and lactate/pyruvate ratios. Additionally, intracranial pressure was reduced significantly in the treatment group, while there were no changes in cerebral perfusion pressure. Unfortunately, one of the limitations of this study was the potential for hyperoxia-induced pulmonary toxicity due to the longevity of the treatment. Magnoni et al performed a variation of the Tolias study by administering 100\% $\mathrm{FiO} 2$ to patients with TBI for $3 \mathrm{~h}$ [44]. Interestingly, similar results were found except that the lactate/pyruvate ratio, and the levels of glucose and glutamate remained unchanged.

In a study by Nortje et al, oxygen- 15 positron emission tomography (15O-PET) analysis revealed that normobaric hyperoxia administered following TBI conferred a preferential metabolic advantage to the "at risk" perilesional tissue, as measured by improved local cerebral metabolic rate of $\mathrm{O}_{2}\left(\mathrm{CMRO}_{2}\right)$ and brain tissue oxygen tension $\left(\mathrm{PbtO}_{2}\right)$ [19]. However, a study from Diringer et al showed that $1 \mathrm{~h}$ hyperoxic treatment was not sufficient to exert positive effects on cerebral $\mathrm{O}_{2}$ metabolism [45]. Cumulative analysis of these studies delineates the beneficial effects of normobaric hyperoxia on TBI. In fact, 
normobaric hyperoxia may offer a simple, minimally invasive, and easily applicable adjunct in the early management of TBI.

\section{Normobaric hyperoxia on stroke}

Several groups have become interested in NBO because it offers distinct advantages over HBO: it is widely available, simple to administer, inexpensive and most importantly, can be started very quickly by paramedics after stroke onset.

Recent rodent studies using the transient middle cerebral artery ischemia-reperfusion model have shown that NBO improves pathological, neurobehavioural, and neuroimaging outcomes following stroke. Singhal et al showed that NBO therapy administered during ischemia and during the immediate post-reperfusion period results in a 70\% reduction of hemispheric infarct volumes in rats $[11,46]$. The therapeutic time window for NBO in rodents is short (approximately 30 45 min); Singhal et al used serial diffusion-weighted imaging (DWI) to show that initiating treatment at earlier time points enhances the degree of neuroprotection and attenuates the severity and the volume of ischemic injury.

The first study on normobaric hyperoxia in stroke was an observational study led by Ronning and Guldvog. Their results showed that the one-year survival was higher in room-air treated control patients with mild-moderate stroke when compared to those treated with $3 \mathrm{~L} / \mathrm{min}$ nasal oxygen [47]. However, there were a lot of shortcomings in this study. For example, the time to treatment was relatively late as $18 \%$ patients did not receive the assigned 'therapy', $12.7 \%$ had hemorrhagic stroke.

The first therapeutic trial of NBO $(45 \mathrm{~L} / \mathrm{min}$ oxygen via a facemask) was carried out by Singhal et al [12]. Results showed that NBO-treated stroke patients had improved National Institutes of Health Stroke Scale (NIHSS) scores, reduced growth of DWI lesion volumes, and an increase in the volume of 'penumbral' tissue. NBO therapy also resulted in a marked improvement in the visibilty of DWI lesions. Additionally, the percentage of MRI voxels improving from baseline "ischemic" to 4-h "non-ischemic" values tended to be higher in NBO-treated patients. Cerebral blood volume and blood flow within ischemic regions also improved with hyperoxia. These findings show that initation of NBO treatment within $12 \mathrm{~h}$ of stroke transiently improves clinical features as well as MRI parameters of ischemia.

Building on their previous work, Singhal et al. performed multivoxel magnetic resonance spectroscopic imaging and diffusion/perfusion MRI in stroke patients exposed to normobaric hyperoxia $(45 \mathrm{~L} / \mathrm{min}$ oxygen through a face mask for $8 \mathrm{~h}$ ), or room air. Imaging, performed before, during, and after therapy, helped conclude that normobaric hyperoxia improves aerobic metabolism [48]. Additionally, a similar study showed that administration of $40 \% \mathrm{FIO}_{2}$ (via venture masks) to patients with middle cerebral artery strokes decreased stroke-related complications as well as mortality [49]. However, these studies need to be further validated due to their small sample size.

\section{Hyperbaric oxygen on traumatic brain injury}

Hyperbaric oxygen treatments typically involve pressurizations between 1.5 and 3.0 ATA for 60 to 120 min daily. A number of studies have demonstrated the effectiveness of HBO in the treatment of TBI using the Glasgow Coma Scale (GCS) and Glasgow Outcome Scale (GOS) to evaluate outcomes. These studies have demonstrated that hyperbaric oxygen treatment increases GCS and GOS scores [50-53]. Additionally, Rockswold et al showed that $\mathrm{HBO}$ therapy could also increase cerebral metabolic rate of oxygen $\left(\mathrm{CMRO}_{2}\right)$ and decrease lactate levels in the CSF, thereby improving aerobic metabolism in patients with severe brain injuries [16,17].

Shi et al used single photon emissions computed tomography (SPECT) images and computed tomography scans (CT) to evaluate the use of HBO therapy on neuropsychiatric disorders following TBI. The results, which revealed that hyperbaric oxygen treatment improved regional cerebral blood flow, were consistent with another study conducted by by Sukoff et al in 1982 [54].

With regards to CSF pressures, Mogami et al. found that CSF pressures of severely brain-injured patients decreased during the beginning of treatment, stayed at a low level during treatment, and rebounded post-treatment [55]. These findings are similar to what Hayakawa et al found a few years later [56].

Although much there have been studies on the efficacy of HBO therapy following TBI, there is insufficient evidence to prove or disprove HBO's therapeutic effectiveness. The evidence indicates that there is a small chance of a mortality benefit with HBO therapy in TBI patients, depending on the subgroup selection. HBO's effect on functional status as well as the incidence and clinical significance of its adverse effects are unclear. In four reviews, the authors consistently concluded that the routine adjunctive use of $\mathrm{HBO}$ therapy in patients with TBI cannot be justified due to various limitations in the existing studies, such as a small number of studies, modest numbers of patients, and the methodological and reporting inadequacies of the primary studies [57-60].

\section{Hyperbaric oxygen on ischemic stroke}

In 1960, Boerema et al showed, for the very first time, that exsanguinated pigs could survive by placing them in a HBO chamber [61]. This study intensified efforts to use HBO to treat organ ischemia. Unfortunately, 3 years later, Jacobson and Lawson reported no benefit following $\mathrm{HBO}$ at 2.0 ATA following MCAO in dogs [62]. But since the 1960 's, numerous animal studies and clinical trials have documented substantial benefits with $\mathrm{HBO}$ in 
animals and/or patients with transient and permanent focal stroke.

Typical HBO therapy regimens use $100 \%$ oxygen at 1.5 2.5 atm pressures for 30 90 min with the time between sessions and the number of sessions varying widely. Recent animal data indicates that oxygen therapy is most effective if applied early, for short durations, and that long-term benefit can be maximized if the tissue is reperfused [63-66]. Delayed and repetitive HBO treatments can expand the therapeutic window in rats with focal cerebral ischemia [67] and can promote neurological recovery in the acute setting, while reducing the frequency of recurrent strokes [68-71].

To this date, three randomized clinical trials using HBO therapy in stroke have been published [72-74], and all three trials have reported negative results. The first trial by Anderson et al was interrupted early due to concerns regarding randomization. Interestingly enough, prior to its discontinuation, the interim analysis revealed a trend towards improvement in neurological examination and infarct volumes in the HBO therapy patient group. In the second trial, conducted by Nighoghossian et al, the Rankin score, Trouillas score, and the Orgogozo scale score, were used to evaluate the effectivess of $\mathrm{HBO}$ therapy. The results showed that Orgogozo and Trouillas scores at 1 year were significantly better in the $\mathrm{HBO}$ group; however, a comparison of the pre-and post-therapy differences between the HBO groups at 6 months and 1 year did not show statistical significance on any of the scoring systems. In the final clinical study, conducted by Rusyniak et al, the results after 3 months revealed that the neurological outcome scores (NIHSS, Rankin scale, Barthel index and Glasgow outcome scale) were significantly better in the sham group (100\% oxygen) compared to the HBO-treated group in all scales except the Barthel index. These clinical studies suggested that HBO therapy does not benefit to ischemic patients and may even be harmful in stroke.

Following these three clinical trials, Bennett et al conducted a meta-analysis and review of the trials, and suggested that existing data do not justify the use of HBO therapy in stroke patients, and that the lack of a significant effect may be related to the small number of patients, delays in initiating HBO therapy, and absence of successful blinding [75].

\section{Hyperoxia Pre-Conditioning}

Pre-conditioning is a process by which an organism's exposure to a stress/stimulus allows it be more resilient against the same stimulus during future encounters. One of the first studies, led by Dahl et al, found that rats preconditioned with a brief episode of anoxia could survive longer $(90 \mathrm{sec})$ than control animals $(60 \mathrm{sec})$ following a prolonged exposure to anoxia [76]. In this study, they speculated that energy metabolism played an important role in the prolonged survival time of the preconditioned rats. This effect was later confirmed in adult brain slices with pre-exposure to a short (5 min) anoxic episode [77]. That same year, Geft et al introduced brief periodic coronary occlusions up to 18 times by inflating and deflating the balloon for periods of 15,10 , or $5 \mathrm{~min}$, followed by 15 -min periods of reperfusion. Their findings suggested that intermittent reperfusion had a beneficial effect and may prevent necrosis, even when total occlusion time exceeds $200 \mathrm{~min}$ [78]. It wasn't until 1986 that Murry et al proposed the concept of pre-conditioning, and confirmed the protective effects of ischemia pre-conditioning on myocardial ischemia [79]. A turning point came when Kitagawa et al documented the ability of brief bilateral carotid occlusion to protect gerbil hippocampal CA1 pyramidal neurons against prolonged global ischemia; these authors coined the term 'ischemic tolerance' to describe the phenomenon [80]. To this date, the protective effects of ischemic pre-conditioning have been confirmed following ischemic exposures to the heart [81], brain [82], lung [83], kidney [84], and liver [85].

Compared with hypoxic pre-conditioning, hyperoxia pre-conditioning via $\mathrm{HBO}$ or $\mathrm{NBO}$ pre-conditioning seems to be a safer and more readily available in clinical practice. In 1986, Martin et al found pre-treatment with endotoxin and pre-conditioning with hyperoxia could reduce the inflammatory response in paraquat-induced neutrophil alveolitis [86]. Four years later, D'Brot et al suggested that prior exposure to alveolar hyperoxia could prevent the hypoxia-induced enhancement of bronchial reactivity to carbachol and histamine, which involves a cyclooxygenase-dependent mechanism [87]. In 1996, a Japanese group showed that repeated exposures to hyperbaric oxygen (100\% oxygen at 2ATA for $1 \mathrm{~h}$ each) could increase the tolerance of the brain against ischemic neuronal damage, in which the induction of HSP-72 synthesis plays an important role [88]. Since then, the protective effects of hyperoxia pre-conditioning, especially the hyperbaric oxygen pre-conditioning, have been investigated in a lot of animal models.

\section{Mechanisms underlying the protective effects of hyperoxia pre-conditioning}

Previous studies have suggested that the protective effects of hyperbaric oxygen pre-conditioning could be attributed heat shock proteins (HSPs) $[88,89]$. However, Vince et al recently suggested that the benefits of $\mathrm{HBO}$ pre-conditioning may not be due to inducement of HSP expression in circulating blood cells, but might involve an enhancement of the stress response [90] (Figure 2).

Exposure to hyperbaric oxygen can generate oxidative stress [91], which can subsequently activate antioxidants that could confer protective effects. Although excessive oxidative stress can damage tissues, previous works have 


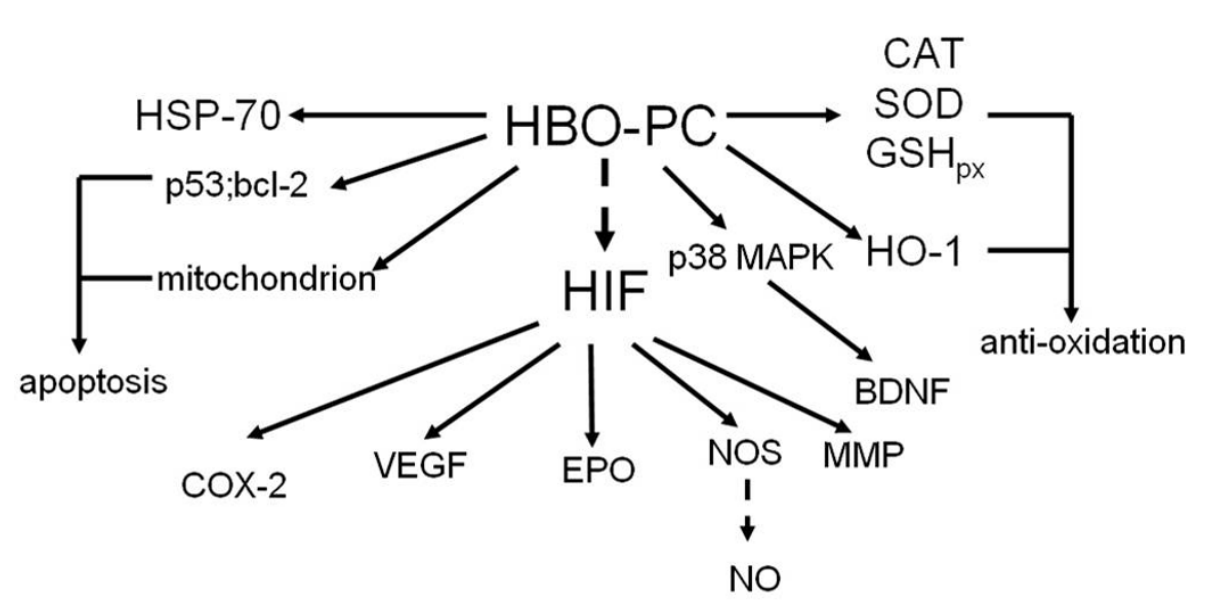

Figure 2 Mechanisms Underlying Hyperoxia Pre-conditioning. The protective effects of hyperoxia pre-conditioning can be attributed to a variety of mechanisms ranging from VEGF activaition to anti-oxidant production.

shown that pre-conditioning with mild hyperoxia can produce an increased antioxidant response [92-98].

Additionally, intermittent exposures to hyperoxia may produce a temporary 'hypoxic environment' between two hyperoxia exposures which may induce the expression and/or activity of a key oxygen sensor known as hypoxiainducible factor-1 (HIF1) $[99,100]$. The increased HIF1 level may regulate the expressions of its downstream genes including vascular endothelial growth factor (VEGF) [101], COX-2 [102,103], erythropoietin (EPO) [100], nitric oxide synthase (NOS) [104] and MMP [105]. Moreover, hyperoxia pre-conditioning can suppress the activity of p38 mitogen activated protein kinase (MAPK) [106-108] and induce expression of brain-derived neurotrophic factors [106], which can also induce the expression of HIF-1 [109].

Other important mechanisms of protection from hyperoxia pre-conditioning include a reduction in apoptosis, especially following ischemic brain injury [106,110-112]. Within the past decade, researchers have also investigated the role of transporters and key inflammatory cytokines, such as glutamate transporters, tumor necrosis factor- $\alpha$, nuclear factor- $\kappa \mathrm{B}$, ribosomal protein S6 kinases, and mitochondrial ATP-sensitive potassium, in the protective effects of hyperoxia pre-conditioning [89,113-116]. Some have even shown that the genes/proteins relevant to neurotrophin and the inflammatory-immune system may be involved in HBO-induced protection [117].

\section{Application of hyperoxia pre-conditioning}

The neuroprotective effects of hyperoxia have been investigated in various models, including global ischemia [105], forebrain ischemia [107], surgical brain injury [102], ischemia-reperfusion injury $[97,110]$, neonatal hypoxia-ischemia [111], intracerebral hemorrhage [89], and spinal cord ischemia [118].

\section{Oxygen toxicity}

Oxygen toxicity is a legitimate concern with regards to the clinical application of hyperbaric oxygen. Once oxygen is applied at a relatively high pressure for prolonged periods of time, various systems and organs can be negatively affected including the central nervous and pulmonary systems [119]. In clinical practice, oxygen is usually applied at 2 3 ATA and the duration of oxygen treatment ranges from $60 \mathrm{~min}$ to $2 \mathrm{~h}$. Moreover, the oxygen inhalation is frequently interrupted by inhalation of air at corresponding pressures. Under these conditions, oxygen toxicity is rare. However, in certain environments, oxygen may be applied at high pressures and for longer durations such as in the treatment of central nervous system decompression sickness/dysbarism [120] and with preemies [121]. Under this condition, the oxygen partial pressure and treatment duration should be closely monitored to minimize the potential for the oxygen toxicity. Although some attempts to minimize the detrimental effects of oxygen exposure with anti-oxidants have been made, nothing has been confirmed [122].

\section{Helium}

\section{Introduction}

In addition to being a well-defined noble gas, helium is the second most abundant element in the universe, and accounts for $24 \%$ of the elemental mass of our galaxy. Helium has many applications in cryogenics, the cooling of superconducting magnets, MRI scanners, arc welding, and can also be used as a gas pressureizer. Helium has traditionally been used to help decrease the incidence of decompression sickness during deep sea diving [123,124].

In 1934, Barach proposed the use of helium as a new therapeutic gas [125], and subsequently proposed heliox (helium/oxygen gas mixture) as a potential therapy for 
asthma exacerbations [126]. Since then, studies have increasingly demonstrated the benefits of heliox inhalational therapy. Within the past decade, heliox has become a focus of renewed interest as treatment for acute asthma exacerbations [127], bronchiolitis [128], chronic obstructive pulmonary disease (COPD) [129]. Heliox has also been recognized as an important adjunct in the treatment of severe asthma exacerbations in the 2007 guidelines published by the National Heart, Lung, and Blood Institute. During treatment of severe asthma exacerbations in children, inhalational heliox therapy led to significant improvements in pulsus paradoxus, peak flow, and dyspnea [130]. The therapeutic effects of helium may be attributed to an increased flow rate and decreased turbulent flow, resulting in deeper penetration of gases to the distal alveoli, higher minute volumes, and improved ventilation. Additionally, helium has been shown to have a high diffusion coefficient for carbon dioxide relative to oxygen. Correspondingly, this diffusion coefficient may facilitate an environment for increased pulmonary exhalation of trapped carbon dioxide (carbon dioxide washout effect), which is another important factor underlying the therapeutic effect of heliox [131].

Despite the first clinical success of heliox use in 1935 and an ample published support over the last decade, heliox is still not widely available in acute care facilities. According to many high level researchers and clinicians, much of the evidence for its use is anecdotal with a paucity of level 1 data. Further studies with homogeneous logistics, a larger patient population, and a more definitive outcome measure are needed to clearly define the utility of heliox.

\section{Biological effects of helium and potential mechanisms}

Helium has been reported to increase the coronary collateral circulation [132] and enhance the vasodilatory effects of inhaled nitric oxide on pulmonary vessels [133] (Table 1). In healthy men, heliox improved exercise tolerance while reducing rising lactate levels, without a significant change in vitals i.e. blood pressure or heart rate [134]. In 2007, Pagel et al applied three cycles of $70 \% \mathrm{He}-30 \% \mathrm{O}_{2}$ for $5 \mathrm{~min}$ interspersed with $5 \mathrm{~min}$ of $70 \% \mathrm{~N}_{2}-30 \% \mathrm{O}_{2}$ before opening up a left anterior descending coronary artery occlusion. Results showed that pre-conditioning with helium could provide cardioprotection by activating pro-survival signaling kinases and inhibiting the opening of the mitochondrial permeability transition pore (mPTP) [135]. In the following year, Heinen et al also applied heliox as a pre-conditioning modality in a rat heart ischemia/reperfusion model. Their results revealed that the cardioprotective effects of heliox pre-conditioning in young rats, which were mediated by mitochondrial uncoupling and $\mathrm{Ca}^{2+}$-sensitive potassium channel activation [136]. In a series of studies led by Pagel et al, researchers found that reactive oxygen species (including nitric oxide) $[137,138]$, mitochondrial adenosine triphosphate-regulated potassium channels, mitochondrial permeability transition [139], and opioid receptors [140] played critical roles in the cardioprotective effects induced by helium preconditioning.

With regards to human clinical trials, Lucchinetti et al reported no protection with helium use. Specifically, 8 healthy adults were recruited to inhale helium at an endtidal concentration of $50 \%$ from 15 min before ischemia to $5 \mathrm{~min}$ after the onset of reperfusion. Although their results indicated that inhaled helium diminishes the postischemic inflammatory reaction, human endothelium was not amenable to protection by helium at $50 \%$ in vivo [141].

\section{Application of helium in neurology}

Few studies have truly investigated the effects of heliox treatment or pre-conditioning in the nervous system. In 2007, Pan et al compared the efficacy of hyperoxia (100\% oxygen) and that of heliox (30\% oxygen/70\% helium) during the ischemia/reperfusion process in the brain [142]. Their results showed that heliox was superior to hyperoxia with regards to infarct volume reductions and improvements in neurological deficits at $24 \mathrm{~h}$. One year later, Coburn et al reported that helium could exert neuroprotective effects at elevated pressures in an in vitro model of traumatic brain injury [2]. However, the exact mechanism underlying the protective effects of heliox has not been reported.

These results seems to conflict with those in the study led by Pan et al, where body temperature, mean arterial blood pressure, heart rate, oxygen saturation and laser Doppler regional cerebral blood flow parameters were not significantly different before, during or after MCAO injury-neither between the control, hyperoxia, nor heliox groups. In addition, to this date two in vitro studies have refuted the protective effects of helium. They reported that heliox was detrimental to neurons [143], and human tubular kidney cells [144].

\section{Xenon}

For decades, volatile anesthetics have been extensively studied with regards to their potential neuroprotective properties. A colorless, heavy, odorless noble gas, xenon has been of particular interest to researchers because of its possible neuroprotective properties.

\section{Biological effects of xenon and potential mechanisms}

Current evidence suggests that xenon induces anesthesia and exerts its analgesic actions by inhibiting the $\mathrm{N}$ methyl-D-aspartate (NMDA) receptor signaling pathway $[145,146]$. Under conditions that mimic synapses of mammalian systems, non-NMDA receptors were found to be insensitive to xenon [147]. Interestingly, xenon 
Table 1 Biological Effects and Potential Mechanisms of Helium

\begin{tabular}{ll}
\hline BIOLOGICAL EFFECTS & POTENTIAL MECHANISMS \\
\hline Coronary Collateral Circulation & Prosurvival Signaling Kinases [137] \\
Improve Exercise Tolerance & MPTP Opening [139] \\
Anti-Arrhythmic Effect & Mitochondrial Uncoupling [136] \\
Anti-Tumor Effect & Ca ${ }^{2+}$-Sensitive Potassium Channel [136]) \\
Anti-Inflammation & Reactive Oxygen Species [137,138] \\
Hypothermia & Mitochondrial ATP-Regulated K ${ }^{+}$Channel [139] \\
High Pressure Nervous Syndrome & Mitochondrial Permeability Transition [139] \\
Neuroprotective Effect & Opioid Receptors [140] \\
Myocardioprotective Effect & COX-2 Activity [23] \\
\hline
\end{tabular}

inhibits the current generated when an artificial agonist (kainite) was directly applied to recombinant AMPA receptors; however, the sensitivity of these receptors to xenon was negligible when they were activated by the natural agonist (glutamate), to mimic synaptic conditions [147].

In addition, xenon can inhibit $\left(\alpha_{4}\right)_{2}\left(\beta_{2}\right)_{3}$ nACh receptors expressed in Xenopus oocytes, whereas the $\alpha_{4} \beta_{4}$ $\mathrm{nACh}$ receptor was only slightly affected [148]. Xenon also competitively blocks the $5 \mathrm{HT} 3 \mathrm{~A}$ receptor, which has been implicated in regulation of emesis and peripheral nociception, at clinically relevant concentrations $[149,150]$. Additionally, Xenon also activates TREK channels [151], which has a neuroprotective role during spinal chord ischemia (Heurteaux et al., 2004).

In addition to acting on receptors, xenon affects neurotransmitter release. In rats, xenon stimulates noradrenergic neurons in the hypothalamus more than nitrous oxide. In vivo microdialysis studies in the rat cerebral cortex revealed that xenon induced an initial increase in ACh release followed by a gradual decrease [152], while there were no xenon-induced effects on acetylcholinesterases in vitro [153]. Additional studies have demonstrated that xenon may act on the secondary messenger signaling pathway via increases in cyclic guanosine monophosphate (cGMP). Galley et al showed that xenon can increase cGMP levels in the spinal cord, brainstem, and hippocampus, without altering the activity of the neuronal nitric oxide synthase [154]. Furthermore, Petzelt et al showed that xenon can influence mechanisms regulating the $\mathrm{Ca}^{2+}$ release channel on plasma membranes [155]. In rat brain synaptic plasma membranes, xenon inhibits plasma membrane calcium ATPase pump activity, resulting in an increase in neuronal $\mathrm{Ca}^{2+}$ concentration and an altered excitability in these cells [156]. The decrease in regional CBF after xenon treatment [157] may help reduce intracranial pressure, and the regional cerebral metabolic rate for glucose [158].

In terms of the cardioprotective effects of xenon, studies have shown that it can stimulate several important intracellular prosurvival signaling kinases, including protein kinase C (PKC) [159,160], MAPK [159,161], HSP 27 [161], extracellular signal-regulated kinases 1/2 [162], Akt, GSK$3 \beta$, and $\mathrm{Ca}^{2+}$-induced mPTP [163]. Xenon's role in antiapoptotic mechanisms also demonstrates its neuroprotective qualities $[164,165]$.

Furthermore, studies have suggested that xenon plays an important role in the anti-inflammatory process. Xenon has been specifically shown to increase the removal of P-selectin glycoprotein ligand-1 (PSGL-1) and L-selectin from the neutrophil surface in vitro. Since both selectins are involved in the initial contact between neutrophils and endothelial cells, xenon may affect neutrophil adhesion to endothelium during ischemia/reperfusion injury [166]. Moreover, xenon has been shown to prevent TNF- $\alpha$-induced expression of ICAM- 1 and to decrease TNF- $\alpha$-induced transcriptional activity of nuclear factor $\kappa \mathrm{B}(\mathrm{NF}-\alpha \mathrm{B})$. However, xenon's protective effect is abolished by functional blockade of COX-2 during xenon-induced late myocardial pre-conditioning [167].

\section{Application of xenon in neurology}

Since the discovery of xenon as an NMDA receptor antagonist, there has been growing interest in its potential use as a neuroprotectant. Some of the features of xenon that specifically interest scientists and researchers include its rapid introduction into the brain, favorable hemodynamic profile with little or no toxicity, and its inability to be be metabolized [168] (Table 2).

Xenon has been shown to be a remarkably potent neuroprotectant in a variety of models [169]. Its dose-dependent neuroprotective effects have been studied in rat neuronal-glial co-cultured with NMDA-induced toxicity, glutamate-induced toxicity, hypoxic injury, and oxygenglucose deprivation [170-172]. The protective effects of xenon have also been identified in rodents subjected to focal ischemia and neonatal hypoxic-ischemic injury $[173,174]$. Additionally, at subanesthetic doses, xenon has been shown to offer global cerebral neuroprotection by reducing the ischemia-induced neurotransmitter release as well as subsequent cell injury and neuronal death that follows an ischemic attack. Maximal neuroprotection was 
Table 2 A Summary of the Neuroprotective Effects of Xenon

\begin{tabular}{|c|c|c|c|}
\hline Model & Intervention & Results & Reference \\
\hline $\begin{array}{l}\text { NMDA, glutamate, or } \\
\text { oxygen deprivation induced } \\
\text { neuronal injury }\end{array}$ & $\begin{array}{l}\text { Xenon saturated medium for } 24 \mathrm{~h} \text { (in } \\
\text { vitro) } \\
20 \%, 40 \%, 60 \%, 75 \% \text { xenon (in vivo) }\end{array}$ & $\begin{array}{l}\text { Xenon ( } 60 \% \mathrm{~atm}) \text { reduces } \mathrm{LDH} \text { release to baseline with oxygen } \\
\text { deprivation; xenon }(75 \% \mathrm{~atm}) \text { reduces } \mathrm{LDH} \text { release by } 80 \% \text { with } \\
\text { either NMDA-or glutamate-induced injury. In vivo, xenon exerts a } \\
\text { concentration-dependent protective effect and reduces injury by } \\
45 \% \text { at the highest xenon concentration tested ( } 75 \% \mathrm{~atm}) \text {. }\end{array}$ & {$[170]$} \\
\hline $\begin{array}{l}\text { Hypoxia damaged cortical } \\
\text { neurons from rat embryos }\end{array}$ & Xenon saturated medium for $2 \mathrm{~h}$ & $\begin{array}{l}\text { Complete protection against cellular damage and prevention of } \\
\text { hypoxia-induced glutamate release }\end{array}$ & {$[171]$} \\
\hline $\begin{array}{l}\text { Hypoxia damaged PC-12 } \\
\text { cells }\end{array}$ & $\begin{array}{l}\text { Xenon saturated medium for up to120 } \\
\text { min }\end{array}$ & $\begin{array}{l}\text { Xenon results in complete protection against cellular damage } \\
\text { and prevention of hypoxia-induced dopamine release in which } \\
\text { intracellular } \mathrm{Ca}^{2+} \text {-ions evolve. }\end{array}$ & [172] \\
\hline MCAO in mice & $\begin{array}{l}70 \%, 35 \% \text { xenon during occlusion for } \\
60 \mathrm{~min}\end{array}$ & $\begin{array}{l}\text { Xenon administration improves both functional and histological } \\
\text { outcome }\end{array}$ & [173] \\
\hline Neonatal HI & $\begin{array}{l}70 \%, 50 \% \text { xenon immediately after } \\
\text { insult for } 3 \mathrm{~h}\end{array}$ & $\begin{array}{l}\text { Xenon administration commenced after hypoxia-ischemia in } \\
\text { neonatal rats provides short-term neuroprotection }\end{array}$ & [174] \\
\hline $\begin{array}{l}\text { brain slices from rats }(O G D) \\
M C A O\end{array}$ & $\begin{array}{l}15-75 \% \text { xenon bubbled medium } \\
50 \% \text { xenon } 2 \sim 3 \mathrm{~h} \text { after MCAO }\end{array}$ & $\begin{array}{l}\text { Xenon, administered at subanesthetic doses, offers global } \\
\text { neuroprotection from reduction of neurotransmitter release } \\
\text { induced by ischemia, reduces subsequent cell injury and } \\
\text { neuronal death }\end{array}$ & [175] \\
\hline $\begin{array}{l}\text { NMA induced neuronal } \\
\text { damage }\end{array}$ & $\begin{array}{l}70 \% \text { xenon for } 10 \text { min at } 3 \mathrm{~h}, 1,2,5 \text {, or } \\
7 \text { days before insult }\end{array}$ & $\begin{array}{l}\text { Xenon alone does not induce changes, but reduces about 50\% } \\
\text { NMDA-induced cell loss as well as degenerating neurons, with } \\
\text { the maximal neuroprotection at } 7 \text { days. }\end{array}$ & {$[176]$} \\
\hline $\begin{array}{l}\text { anesthetic-induced neuronal } \\
\text { apoptosis in vivo and in } \\
\text { vitro }\end{array}$ & $75 \%, 60 \%, 30 \%$ xenon for $6 \mathrm{~h}$ & Xenon attenuates isoflurane-induced apoptosis. & [164] \\
\hline $\begin{array}{l}\text { nitrous oxide and isoflurane } \\
\text { induced damage }\end{array}$ & $70 \%$ xenon for $2 \mathrm{~h}$ & $\begin{array}{l}\text { Xenon pre-treatment prevents nitrous oxide-and isoflurane- } \\
\text { induced neuroapoptosis (in vivo and in vitro) and cognitive } \\
\text { deterioration (in vivo) }\end{array}$ & [165] \\
\hline $\begin{array}{l}\text { OGD induced damage to } \\
\text { neurons from neonatal mice }\end{array}$ & $\begin{array}{l}\text { 75\% xenon + Dex }(0.001 \sim 10 \mu \mathrm{M}) \text { for } 6 \\
\mathrm{~h}\end{array}$ & $\begin{array}{l}\text { Combination of Xenon and Dex offers neuroprotection } \\
\text { additively in vitro and synergistically in vivo }\end{array}$ & [178] \\
\hline neonatal $\mathrm{HI}$ & $\begin{array}{l}20-70 \% \text { xenon for } 90 \text { min during } \\
\text { hypoxia or } 2,24 \mathrm{~h} \text { after hypoxia }+ \\
\text { hypothermia }\left(30-37^{\circ} \mathrm{C}\right)\end{array}$ & $\begin{array}{l}\text { Xenon and hypothermia administered } 4 \mathrm{~h} \text { after hypoxic- } \\
\text { ischemic injury in neonatal rats provides synergistic } \\
\text { neuroprotection }\end{array}$ & {$[177]$} \\
\hline $\begin{array}{l}\text { OGD induced damage to } \\
\text { neurons; neonatal HI }\end{array}$ & $\begin{array}{l}25 \sim 75 \% \text { xenon for } 120 \text { min (in vitro); } \\
70 \% \text { xenon for } 120 \text { min (in vivo) }\end{array}$ & $\begin{array}{l}\text { Prosurvival proteins } \mathrm{BCl}-2 \text { and brain-derived neurotrophic factor } \\
\text { are upregulated by xenon treatment }\end{array}$ & [179] \\
\hline $\begin{array}{l}\text { OGD induced damage to } \\
\text { neurons; neonatal HI }\end{array}$ & $\begin{array}{l}12.5 \sim 75 \% \text { xenon for } 2 \text { h (in vitro); } 20 \% \text {, } \\
75 \% \text { for } 2 \text { h (in vivo) }\end{array}$ & $\begin{array}{l}\text { Pre-conditioning with xenon and the combination of xenon and } \\
\text { sevoflurane results in long-term functional neuroprotection } \\
\text { associated with enhanced phosphorylated cyclic adenosine } \\
\text { monophosphate response element binding protein signaling }\end{array}$ & [180] \\
\hline MCAO in mice & $70 \%$ xenon for $2 \mathrm{~h}$ & $\begin{array}{l}\text { Xenon pre-conditioning improves histological and neurological } \\
\text { functional outcome in both genders in a stroke model of mice } \\
\text { in which HIF-1 } \alpha \text { and phosphoAkt evolve }\end{array}$ & [207] \\
\hline $\begin{array}{l}\text { OGD induced damage to } \\
\text { neurons }\end{array}$ & $75 \%$ xenon for $2 \mathrm{~h}$ & $\begin{array}{l}\text { Xenon pre-conditioning clearly involves the activation of } \mathrm{K}_{\text {ATP }} \\
\text { channels. }\end{array}$ & [208] \\
\hline
\end{tabular}

obtained at a concentration dose of $50 \%$, even when xenon was administered up to $4 \mathrm{~h}$ after intrastriatal NMDA injection and up to at least $2 \mathrm{~h}$ following the induction of transient brain ischemia [175].

In one study, Natale et al investigated the neuroprotective properties of xenon by evaluating its morphological changes on rat arcuate nucleus. After 3 h, 1, 2, 5, or 7 days from gas exposure, the neuronal damage was significantly reduced in the xenon treatment group. They concluded that xenon could be regarded as a promising neuroprotective agent [176]. In a neonatal hypoxia-ischemia model, Dingley et al showed that $3 \mathrm{~h}$ of xenon administration, following hypoxia-ischemia, provided short-term neuroprotection in neonatal rats [174].
Researchers have also explored the possibility of using xenon in combination with other therapeutic strategies to evaluate its possible synergistic neuroprotective capabilities. In one study, a combination of xenon and hypothermia, administered $4 \mathrm{~h}$ following hypoxicischemic injury, provided synergistic neuroprotection in neonatal rats [177]. Studies also revealed that the combination of xenon and dexamethasone could offer additive neuroprotection both in vitro and in vivo [178] (Table 2)

Recently, xenon has been investigated as a brain preconditioning agent. Ma et al observed that xenoninduced pre-treatment in neonatal hypoxic-ischemic rats decreased infarction size and improved neurological function [179]. Additional pre-conditioning studies with 
xenon alone and with the addition of sevoflurane resulted in long-term functional neuroprotection associated with enhanced phosphorylated cyclic adenosine monophosphate response element binding protein signaling [180]. Xenon pre-treatment prevented nitrous oxide-and isoflurane-induced neuroapoptosis (in vivo and in vitro) and cognitive deterioration (in vivo) [165].

\section{Hydrogen}

The first element in the periodic table is hydrogen $\left(\mathrm{H}_{2}\right)$. As the lightest and most abundant chemical element, hydrogen constitutes roughly $75 \%$ of the Universe's chemical elemental mass. In comparison, free hydrogen is rare on Earth, constituting less than 1 part per million in the atmosphere, with the majority found in water and organic compounds.

Hydrogen is continuously synthesized in human cells during fermentation of non-digestible carbohydrates by intestinal bacteriain the large intestine, and is later excreted as flatus $[181,182]$. This is the basis for the routinely-used breath hydrogen as a test for gastrointestinal transit. An estimated $14 \%$ to $20 \%$ of the total colonic $\mathrm{H}_{2}$ production was reported to be carried through the human bloodstream and subsequently released into the lungs [183]. Therefore, exhalation of hydrogen forms the basis for assessing gastrointestinal motility and transit time as well as the overgrowth of of small intestinal bacterial [184-186].

In 1975, Dole et al first applied hyperbaric hydrogen when treating mice with squamous cell carcinoma [187]. Since their results revealed significant regression of tumors, they speculated that hyperbaric hydrogen therapy may act as a free radical decay catalyzer and prove efficacious in other cancer types [187]. On the other hand, Kayar et al showed hydrogen gas is not oxidized by mammalian tissues under hyperbaric conditions and instead attributed its effect to other unknown properties [188]. It wasn't until 2001 that Gharib et al investigated the anti-inflammatory properties of hydrogen in a schistosomiasis-associated chronic liver inflammation model. The results revealed that hyperbaric hydrogen at $0.7 \mathrm{MPa}$ for 2 weeks had significant protective effects on liver injury by decreasing fibrosis while improving hemodynamics and the activity of antioxidant enzymes [189]. However, few studies emphasized the therapeutic effects of hydrogen before 2007. This was when a Japanese group conducted a series of experiments investigating the biological effects and therapeutic potency of hydrogen ( 4\%) [190]. Since then, a large number of studies have explored the therapeutic effects of hydrogen in different tissues including the brain, heart, kidney, lung, and liver.

\section{Mechanisms underlying the bioeffects of hydrogen}

One of hydrogen's antioxidant capabilities is as a free radical scavenger. It selectively reduces the levels of hydroxyl radicals $(\cdot \mathrm{OH})$, which are mainly generated through the Fenton reaction and peroxynitrite $\left(\mathrm{ONOO}^{-}\right)$ in vitro [190], and are both strong oxidants that react indiscriminately with nucleic acids, lipids, and proteins to cause DNA fragmentation, lipid peroxidation, and protein inactivation. Another possible mechanism underlying the cellular protection afforded by hydrogen may be its ability to increase antioxidant enzymes such as catalase, superoxide dismutase, and heme oxygenase$1[191,192]$. Some studies have suggested that hydrogen may have antiapoptotic properties, and can inhibit caspace-3 activation [193].

Therefore, hydrogen has several potential advantages over current pharmacological due to its safety and therapeutic potency. Hydrogen's ability to easily traverse the brain-blood barrier allows it to be safely administered to human patients. Furthermore, it is capable of rapidly diffusing through membrane compartments to gain ready access to the cytosol, mitochondria, and nucleus. Finally, hydrogen reduces detrimental hydroxyl radicals and peroxynitrite, but does not compromise essential homeostatic mechanisms dependent on ROS.

\section{Application of hydrogen in neurology}

The potential benefits of hydrogen gas on various brain pathologies have been investigated since 2007, when the first hydrogen paper was published (Table 3). In China $[194,195]$ researchers found that inhalation of $2 \%$ hydrogen and injection of hydrogen-saturated saline following hypoxic-ischemic brain injuries evoked neuroprotection via inhibition of neuronal apoptosis and reduction of caspase- 3 and caspase- 12 activities. These short-term effects also translated into long-term improvements in when neurobehavioral functions were tested 5 weeks following the injury [195]. However, Matchett et al reported conflicting results [196] in moderate and severe neonatal brain hypoxia (HI) models. In their study, inhalation of $2.9 \%$ hydrogen did not decrease the infarction volume and brain lipid peroxidation, but there was a trend suggesting a beneficial effect on middle cerebral artery occlusion in adult rats. These discrepancies might be attributed to differing experimental conditions (different degrees of $\mathrm{HI}$ insult, age of pups, concentration of hydrogen, and length of hydrogen exposure). Additionally, Sato et al [197] reported that administering hydrogen-rich water to vitamin C-depleted SMP30/GNL knockout mice during both hypoxia and regeneration markedly decreased the levels of hydroxyl and superoxide in brain slices. Li et al [198], examined if hydrogen-rich saline reduced amyloid $\beta(A \beta)$ induced neural inflammation, as well as learning and memory deficits in a rat model. The results showed that intraperitoneal injections of hydrogen-rich saline, which were administerd daily once for 2 consecutive weeks, could improve the cognitive and memory functions in rat models with amyloid $\beta$ 1-42-induced Alzheimer's by 
Table 3 Summary of Neuroprotective Effect of Hydrogen

\begin{tabular}{|c|c|c|c|}
\hline Model & Intervention & Results & Reference \\
\hline $\mathrm{MCAO}$ & $\begin{array}{l}1 \%, 2 \%, 4 \% \text { hydrogen during the occlusion } \\
(85 \mathrm{~min}) \text {, or reperfusion ( } 35 \mathrm{~min}) \text { or } \\
\text { occlusion + reperfusion (120 min) }\end{array}$ & $\begin{array}{l}\text { Inhalation of hydrogen markedly suppresses brain injury } \\
\text { by buffering the effects of oxidative stress. } 2 \% \text { hydrogen } \\
\text { is more effective than } 4 \% \text { and } 1 \% \text { hydrogen }\end{array}$ & [190] \\
\hline neonatal $\mathrm{HI}$ & $\begin{array}{l}2 \% \text { hydrogen }(30,60 \text { and } 120 \mathrm{~min}) \text { or } \\
\text { hydrogen saturated saline }(5 \mathrm{ml} / \mathrm{kg} \\
\text { immediately and } 8 \mathrm{~h} \text { after insult) }\end{array}$ & $\begin{array}{l}\text { Hydrogen treatment significantly reduces the apoptotic } \\
\text { cells, suppresses caspase- } 3 \text { and }-12 \text { activities, reduces } \\
\text { MDA and lba- } 1 \text { levels, and improves the long-term } \\
\text { neurological and neurobehavioral functions }\end{array}$ & {$[194,195]$} \\
\hline newborn pig asphyxia & $\begin{array}{l}2.1 \% \mathrm{H}_{2} \text {-supplemented room air for } 1 \mathrm{~h} \\
\text { and additional } 3 \mathrm{~h}\end{array}$ & $\begin{array}{l}\mathrm{H}_{2} \text {-RA ventilation significantly increases cerebrovascular } \\
\text { reactivity to hypercapnia after asphyxia/reventilation; no } \\
\text { affects on ROS-dependent cerebrovascular reactivity to } \\
\text { NMDA }\end{array}$ & [209] \\
\hline $\begin{array}{l}\text { neonatal } \mathrm{HI} \\
\text { MCAO }\end{array}$ & Inhalation of $2.9 \%$ hydrogen & $\begin{array}{l}\text { Inhalation of } 2.9 \% \text { hydrogen did not decrease the } \\
\text { infarction volume and brain lipid peroxidation, but there } \\
\text { was a trend suggesting a beneficial effect on MCAO in } \\
\text { adult rats }\end{array}$ & [196] \\
\hline $\begin{array}{l}\text { hypoxia-reoxygenation of brain } \\
\text { slices of vitamin C-depleted } \\
\text { SMP30/GNL knockout mice }\end{array}$ & hydrogen-rich pure water & $\begin{array}{l}\text { Hydrogen-rich pure water acts as an anti-oxidant and } \\
\text { prevents superoxide formation }\end{array}$ & [197] \\
\hline $\begin{array}{l}\text { amyloid- } \beta \text {-induced Alzheimer's } \\
\text { disease }\end{array}$ & $\begin{array}{l}\text { Intraperitoneal hydrogen rich saline }(5 \mathrm{ml} / \\
\mathrm{kg} \text { daily for } 2 \text { weeks) }\end{array}$ & $\begin{array}{l}\text { Hydrogen-rich saline prevents beta-induced } \\
\text { neuroinflammation and oxidative stress, which may } \\
\text { contribute to the improvement of memory dysfunction } \\
\text { in this rat model }\end{array}$ & [198] \\
\hline MCAO & $\begin{array}{l}\text { Inhalation of } 2.9 \% \text { hydrogen during } \\
\text { reperfusion }\end{array}$ & $\begin{array}{l}\text { Inhalation of hydrogen during } 2 \mathrm{~h} \text { reperfusion was } \\
\text { found to reduce brain infarction, hemorrhagic } \\
\text { transformation, and improve neurological function }\end{array}$ & [199] \\
\hline chronic physical restraint in mice & $\begin{array}{l}\text { Oral intake of hydrogen supplemented } \\
\text { water up to } 8 \text { weeks }\end{array}$ & $\begin{array}{l}\text { Hydrogen water reduces oxidative stress in the brain, } \\
\text { and prevents the stress-induced decline in learning and } \\
\text { memory caused by chronic physical restraint }\end{array}$ & {$[200]$} \\
\hline $\begin{array}{l}\text { MPTP induced Parkinson's } \\
\text { disease model }\end{array}$ & $\begin{array}{l}\text { Oral intake of hydrogen containing water } \\
\text { for } 28 \text { days }\end{array}$ & $\begin{array}{l}\text { Drinking hydrogen-containing water significantly } \\
\text { reduces the loss of dopaminergic neurons accompanied } \\
\text { by significant reduction of oxidative stress which was } \\
\text { demonstrated by a significant decrease of DNA damage } \\
\text { and lipid peroxidation. }\end{array}$ & [201] \\
\hline $\begin{array}{l}\text { 6-OHDA induced Parkinson's } \\
\text { disease model }\end{array}$ & $\begin{array}{l}\text { Oral intake of hydrogen containing water } \\
\text { before and after surgery }\end{array}$ & $\begin{array}{l}\text { Prevent both the development and progression of the } \\
\text { nigrostrital degeneration and dopaminergic cell loss }\end{array}$ & [202] \\
\hline Senescence-accelerated mice & $\begin{array}{l}\text { Oral intake of hydrogen containing water } \\
\text { for } 30 \text { days and } 18 \text { weeks }\end{array}$ & $\begin{array}{l}\text { Prevented age-related declines in cognitive ability } \\
\text { increases brain serotonin levels and elevates serum } \\
\text { antioxidant activity at } 30 \text { days while inhibiting } \\
\text { neurodegeneration in the hippocampus at } 18 \text { weeks }\end{array}$ & [203] \\
\hline
\end{tabular}

preventing neuro-inflammation and oxidative stress. In a middle cerebral artery occlusion model, administering injections of $50 \%$ dextrose, and hydrogen gas during the reperfusion (for $2 \mathrm{~h}$ ) reduced brain infarction, hemorrhagic transformation, and improved neurological function in rats [199].

Oral intake of hydrogen-supplemented water is an alternative mode of hydrogen delivery. Nagata et al [200] tested a hypothesis that drinking hydrogen water ad libitum, instead of inhaling hydrogen gas, prevents cognitive impairment by reducing oxidative stress. Their findings demonstrated that the consumption of hydrogen water could prevent the stress (chronic physical restraint)induced decline in learning and memory in a mouse model via reduction of oxidative stress. In a 1-methyl-4phenyl-1,2,3,6-tetrahydropyridine (MPTP)-induced Parkinson's disease model, Fujita et al showed that drinking hydrogen-containing water (even as low as $0.04 \mathrm{mM}$ ) significantly reduced the loss of dopaminergic neuron. Additionally, reductions in oxidative stress were demonstrated by a significant decrease of 8-oxoguanine (8-oxoG), a marker of DNA damage, and 4-hydroxynonenal (4-HNE), a marker of lipid peroxidation [201]. In a rat Parkinson's disease model induced by intrastriatal injection of catecholaminergic neurotoxin 6-hydroxydopamine (6-OHDA), Fu et al found that oral intake of hydrogen water could prevent both the development and progression of nigrostrital degeneration, and pre-and post-treatment with hydrogen prevented dopaminergic cell loss [202]. Therefore, they concluded that hydrogen water was likely to retard the development and progression of Parkinson's disease. Gu et al investigated the efficacies of drinking hydrogen water to prevent spatial memory decline and age-related brain alterations. 
Treating senescence-accelerated prone mouse 8 (SAMP8) with hydrogen water for 30 days was found to prevent age-related declines in cognitive ability, which were associated with increased brain serotonin levels, elevated serum antioxidant activity, and inhibition of neurodegeneration in the hippocampus [203].

\section{Argon}

The neuroprotective effects of argon have been confirmed in both in vivo and in vitro studies. One study led by Ryang et al., analyzed the possible neuroprotective role of argon post-treatment in an in vivo rat model of acute focal cerebral ischemia [204]. They found that animals breathing spontaneously $50 \mathrm{vol} \%$ argon $1 \mathrm{hr}$ after induction of transient middle cerebral artery occlusion for $1 \mathrm{hr}$ by face mask showed significantly reduced infarct volumes and composite adverse outcomes. Similarly, Loetscher et al. showed using in vitro studies that argon post-treatment could reduce damages following oxygen-glucose deprivation and traumatic brain injury [205]. Although both studies along with various other studies [206] published in the literature have shown favorable support for Argon's neuroprotective characteristics, evidence is lacking with regards to the exact mechanism and more studies are required to clarify these mechanisms.

\section{Conclusion}

Although the protective effects of the aforementioned gases have been extensively investigated as a therapeutic option following various neurobiological diseases and events, the definite efficacy and mechanisms of action of these gases should be further validated in more welldesigned, clinical trials.

\section{Acknowledgements}

This study is partially supported by NIH grants NS06093 and NS053407.

\section{Author details}

'Department of Diving Medicine, The Second Military Medical University, Shanghai, China. ${ }^{2}$ Department of Anesthesiology, Loma Linda Medical Center, Loma Linda, California, USA. ${ }^{3}$ Department of Neurosurgery, Loma Linda Medical Center, Loma Linda, California, USA.

\section{Authors' contributions}

WL-Role included study design, conduct of the study, data collection and analysis. NHK-Role included study design and manuscript preparation. AS Role included study design and manuscript preparation. JHZ-Role included study design, conduct of the study, data collection and analysis. All authors read and approved the final manuscript.

\section{Competing interests}

The authors declare that they have no competing interests.

Received: 1 March 2011 Accepted: 27 June 2011

Published: 27 June 2011

\section{References}

1. Li L, Hsu A, Moore PK: Actions and interactions of nitric oxide, carbon monoxide and hydrogen sulphide in the cardiovascular system and in inflammation-a tale of three gases! Pharmacol Ther. 2009, 123(3):386-400.

2. Coburn M, Maze M, Franks NP: The neuroprotective effects of xenon and helium in an in vitro model of traumatic brain injury. Crit Care Med 2008, 36(2):588-95.

3. Derwall M, Coburn M, Rex S, Hein M, Rossaint R, Fries M: Xenon: recent developments and future perspectives. Minerva Anestesiol 2009, 75(12):37-45.

4. David HN, Haelewyn B, Chazalviel L, Lecoca M, Degoulet M, Risso JJ, Abraini $\mathrm{JH}$ : Post-ischemic helium provides neuroprotection in rats subjected to middle cerebral artery occlusion-induced ischemia by producing hypothermia. J Cereb Blood Flow Metab 2009, 29(6):1159-65.

5. Folkman J, Hahnfeldt P, Hlatky L: Cancer: looking outside the genome. Nat Rev Mol Cell Biol 2000, 1(1):76-9.

6. Gatenby RA, Gillies RJ: Why do cancers have high aerobic glycolysis? Nat Rev Cancer 2004, 4(11):891-9.

7. Tibbles PM, Edelsberg JS: Hyperbaric-oxygen therapy. N Engl J Med 1996, 334(25):1642-8.

8. Belda J, Aguilera L, de la Asuncion JG, Alberti J, Vicente R, Fernandiz L, Rodriguez R, Company B, Sessler DI, Aguilar G, Botello SG, Orti R: Supplemental perioperative oxygen and the risk of surgical wound infection, a randomized controlled study. J Am Med Assoc 2005, 294:2035-2042.

9. Mathieu D, Wattel F: Physiologic effects of hyperbaric oxygen on microorganisms and host defences against infection. In Handbook on Hyperbaric Medicine. Edited by: Mathieu D. Dordrecht, The Netherlands: Springer; 2006:103-119.

10. Lambertsen CJ: Effects of oxygen at high partial pressure. In Handbook of Physiology: Respiration. Volume 2. Edited by: Fenn WO, Rahn H. Bethesda, MD: American Physiological Society; 1965:1027-1046, Section 3.

11. Singhal AB, Dijkhuizen RM, Rosen BR, Lo EH: Normobaric hyperoxia reduces $M R I$ diffusion abnormalities and infarct size in experimental stroke. Neurology 2002, 58(6):945-52.

12. Singhal $A B$, Benner $T$, Roccatagliata $L$, Koroshetz WJ, Schaefer PW, Lo EH, Buonanno FS, Gonzalez RG, Sorensen AG: A pilot study of normobaric oxygen therapy in acute ischemic stroke. Stroke 2005, 36(4):797-802.

13. Kety SS, Schmidt CF: The effects of altered arterial tensions of carbon dioxide and oxygen on cerebral blood flow and cerebral oxygen consumption of normal young men. J Clin Invest 1948, 27(4):484-92.

14. Omae T, Ibayashi S, Kusuda K, Nakamura H, Yagi H, Fujishima M: Effects of high atmospheric pressure and oxygen on middle cerebral blood flow velocity in humans measured by transcranial Doppler. Stroke 1998, 29(1):94-7.

15. Johnston AJ, Steiner LA, Gupta AK, Menon DK: Cerebral oxygen vasoreactivity and cerebral tissue oxygen reactivity. $\mathrm{Br} J$ Anaesth 2003 90(6):774-86.

16. Daugherty WP, Levasseur JE, Sun D, Rockswold GL, Bullock MR: Effects of hyperbaric oxygen therapy on cerebral oxygenation and mitochondrial function following moderate lateral fluid-percussion injury in rats. $J$ Neurosurg 2004, 101(3):499-504.

17. Rockswold SB, Rockswold GL, Vargo JM, Erickson CA, Sutton RL, Bergman TA, Biros MH: Effects of hyperbaric oxygenation therapy on cerebral metabolism and intracranial pressure in severely brain injured patients. J Neurosurg 2001, 94(3):403-11.

18. Rockswold SB, Rockswold GL, Zaun DA, Zhang X, Cerra CE, Bergman TA, Liu J: A prospective, randomized clinical trial to compare the effect of hyperbaric to normobaric hyperoxia on cerebral metabolism, intracranial pressure, and oxygen toxicity in severe traumatic brain injury. J Neurosurg 2010, 112(5):1080-94.

19. Nortje J, Coles JP, Timofeev I, Fryer TD, Aigbirhio FI, Smielewski P, Outtrim JG, Chatfield DA, Pickard JD, Hutchinson PJ, Gupta AK, Menon DK: Effect of hyperoxia on regional oxygenation and metabolism after severe traumatic brain injury: preliminary findings. Crit Care Med 2008, 36(1):273-81.

20. Lou M, Zhang H, Wang J, Wen SQ, Tang ZQ, Chen YZ, Yan WQ, Ding MP: Hyperbaric oxygen treatment attenuated the decrease in regional glucose metabolism of rats subjected to focal cerebral ischemia: a high resolution positron emission tomography study. Neuroscience 2007, 146(2):555-61.

21. Chen $Q$, Banick PD, Thom SR: Functional inhibition of rat polymorphonuclear leukocyte B2 integrins by hyperbaric oxygen is 
associated with impaired cGMP synthesis. J Pharmacol Exp Ther 1996, 276:929-933.

22. Sukhotnik I, Coran AG, Greenblatt R, Brod V, Mogilner J, Shiloni E, Shaoul R, Bitterman H: Effect of $100 \%$ oxygen on E-selectin expression, recruitment of neutrophils and enterocyte apoptosis following intestinal ischemiareperfusion in a rat. Pediatr Surg Int 2008, 24(1):29-35.

23. Buras JA, Stahl GL, Svoboda KS, Reenstra WR: Hyperbaric oxygen downregulates ICAM-1 expression induced by hypoxia and hypoglycaemia: the role of eNOS. Am J Physiol 2000, 278:C292-C302.

24. Jones SR, Carpin KM, Woodward SM, Khiabani KT, Stephenson LL, Wang WZ, Zamboni WA: Hyperbaric oxygen inhibits ischemiareperfusion-induced neutrophil CD18 polarization by a nitric oxide mechanism. Plast Reconstr Surg 2010, 126(2):403-11.

25. Buras JA, Reenstra WR: Endothelial-neutrophil interactions during ischemia and reperfusion injury: basic mechanisms of hyperbaric oxygen. Neurol Res 2007, 29(2):127-31.

26. Yin W, Badr AE, Mychaskiw G, Zhang JH: Down regulation of COX-2 is involved in hyperbaric oxygen treatment in a rat transient focal cerebral ischemia model. Brain Res 2002, 926:165-71.

27. Rink C, Roy S, Khan M, Ananth P, Kuppusamy P, Sen CK, Khanna S: Oxygensensitive outcomes and gene expression in acute ischemic stroke. J Cereb Blood Flow Metab 2010, 30(7):1275-87.

28. Yin D, Zhou C, Kusaka I, Calvert JW, Parent AD, Nanda A, Zhang JH: Inhibition of apoptosis by hyperbaric oxygen in a rat focal cerebral ischemic model. J Cereb Blood Flow Metab 2003, 23(7):855-64.

29. Calvert JW, Zhou C, Nanda A, Zhang JH: Effect of hyperbaric oxygen on apoptosis in neonatal hypoxia-ischemia rat model. J Appl Physiol 2003, 95(5):2072-80.

30. Henninger N, Bouley J, Nelligan JM, Sicard KM, Fisher M: Normobaric hyperoxia delays perfusion/diffusion mismatch evolution, reduces infarct volume, and differentially affects neuronal cell death pathways after suture middle cerebral artery occlusion in rats. J Cereb Blood Flow Metab 2007, 27(9):1632-42.

31. Qin Z, Karabiyikoglu M, Hua Y, Silbergleit R, He Y, Keep RF, Xi G: Hyperbaric oxygen-induced attenuation of hemorrhagic transformation after experimental focal transient cerebral ischemia. Stroke 2007 , 38(4):1362-7

32. Veltkamp R, Siebing DA, Sun L, Heiland S, Bieber K, Marti HH, Nagel S, Schwab S, Schwaninger M: Hyperbaric oxygen reduces blood-brain barrier damage and edema after transient focal cerebral ischemia. Stroke 2005, 36(8):1679-83.

33. Sun L, Zhou W, Mueller C, Sommer C, Heiland S, Bauer AT, Marti HH, Veltkamp R: Oxygen therapy reduces secondary hemorrhage after thrombolysis in thromboembolic cerebral ischemia. J Cereb Blood Flow Metab 2010, 30(9):1651-60.

34. Liu W, Hendren J, Qin XJ, Shen J, Liu KJ: Normobaric hyperoxia attenuates early blood-brain barrier disruption by inhibiting MMP-9-mediated occludin degradation in focal cerebral ischemia. J Neurochem 2009, 108(3):811-20.

35. Liu W, Sood R, Chen Q, Sakoglu U, Hendren J, Cetin O, Miyake M, Liu KJ: Normobaric hyperoxia inhibits NADPH oxidase-mediated matrix metalloproteinase- 9 induction in cerebral microvessels in experimental stroke. J Neurochem 2008, 107(5):1196-205.

36. Sun L, Marti HH, Veltkamp R: Hyperbaric oxygen reduces tissue hypoxia and hypoxia-inducible factor-1 alpha expression in focal cerebral ischemia. Stroke 2008, 39(3):1000-6.

37. Liu JK, Rosenberg GA: Matrix metalloproteinases and free radicals in cerebral ischemia. Free Radic Biol Med 2005, 39(1):71-80.

38. Rosenberg GA, Yang Y: Vasogenic edema due to tight junction disruption by matrix metalloproteinases in cerebral ischemia. Neurosurg Focus 2007, 22(5):E4.

39. Zhou C, Li Y, Nanda A, Zhang JH: HBO suppresses Nogo-A, Ng-R, or RhoA expression in the cerebral cortex after global ischemia. Biochem Biophys Res Commun 2003, 309(2):368-76.

40. Garcia AJ, Putnam RW, Dean JB: Hyperbaric hyperoxia and normobaric reoxygenation increase excitability and activate oxygen-induced potentiation in CA1 hippocampal neurons. J Appl Physiol 2010, 109(3):804-19.

41. Ma MM, Zhang L, Liu BQ: [Influence of hyperbaric oxygen treatment on neural plasticity in experimental rats]. [Article in Chinese] Zhong Nan Da Xue Xue Bao Yi Xue Ban 2008, 33(12):1113-8.
42. Thiagarajan A, Goverdhan PD, Chari P, Somasunderam K: The effect of hyperventilation and hyperoxia on cerebral venous oxygen saturation in patients with traumatic brain injury. Anesth Analg 1998, 87(4):850-3.

43. Tolias CM, Reinert M, Seiler R, Gilman C, Scharf A, Bullock MR: Normobaric hyperoxia-induced improvement in cerebral metabolism and reduction in intracranial pressure in patients with severe head injury: a prospective historical cohort-matched study. J Neurosurg 2004, 101(3):435-44.

44. Magnoni S, Ghisoni L, Locatelli M, Caimi M, Colombo A, Valeriani V, Stocchetti N: Lack of improvement in cerebral metabolism after hyperoxia in severe head injury: a microdialysis study. J Neurosurg 2003, 98(5):952-8.

45. Diringer MN, Aiyagari V, Zazulia AR, Videen TO, Powers WJ: Effect of hyperoxia on cerebral metabolic rate for oxygen measured using positron emission tomography in patients with acute severe head injury. J Neurosurg 2007, 106(4):526-9.

46. Singhal $A B$, Wang $X$, Sumii $T$, Mori $T$, Lo EH: Effects of normobaric hyperoxia in a rat model of focal cerebral ischemia-reperfusion. J Cereb Blood Flow Metab 2002, 22(7):861-8.

47. Ronning OM, Guldvog B: Should stroke victims routinely receive supplemental oxygen? A quasi-randomized controlled trial. Stroke 1999, 30(10):2033-7.

48. Singhal AB, Ratai E, Benner T, Vangel M, Lee V, Koroshetz WJ, Schaefer PW, Sorensen AG, Gonzalez RG: Magnetic resonance spectroscopy study of oxygen therapy in ischemic stroke. Stroke 2007, 38(10):2851-4

49. Chiu EH, Liu CS, Tan TY, Chang KC: Venturi mask adjuvant oxygen therapy in severe acute ischemic stroke. Arch Neurol 2006, 63(5):741-4

50. Xie ZY, Zhuang MH, Lin L, Xu HW, Chen LX, Hu LN: Changes of plasma Creactive protein in patients with craniocerebral injury before and after hyperbaric oxygenation: A randomly controlled study. Neural Regeneration Research 2007, 2(5):314-7.

51. Ren H, Wang W, Ge Z: Glasgow Coma Scale, brain electric activity mapping and Glasgow Outcome Scale after hyperbaric oxygen treatment of severe brain injury. Chin J Traumatol 2001, 4(4):239-41.

52. Rockswold GL, Ford SE, Anderson DC, Bergman TA, Sherman RE: Results of a prospective randomized trial for treatment of severely braininjured patients with hyperbaric oxygen. J Neurosurg 1992, 76(6):929-34.

53. Lin JW, Tsai JT, Lee LM, Lin CM, Hung CC, Hung KS, Chen WY, Wei L, Ko CP Su YK, Chiu WT: Effect of hyperbaric oxygen on patients with traumatic brain injury. Acta Neurochir Supp/ 2008, 101:145-9.

54. Sukoff MH, Ragatz RE: Hyperbaric oxygenation for the treatment of acute cerebral edema. Neurosurgery 1982, 10(1):29-38.

55. Mogami H, Hayakawa T, Kanai N, Kuroda R, Yamada R, Ikeda T, Katsurada K, Sugimoto T: Clinical application of hyperbaric oxygenation in the treatment of acute cerebral damage. J Neurosurg 1969, 31(6):636-43.

56. Hayakawa T, Kanai N, Kuroda R, Yamada R, Mogami H: Response of cerebrospinal fluid pressure to hyperbaric oxygenation. J Neurol Neurosurg Psychiatry 1971, 34(5):580-6.

57. Bennett MH, Trytko B, Jonker B: Hyperbaric oxygen therapy for the adjunctive treatment of traumatic brain injury. Cochrane Database Syst Rev 2004, 4: CD004609.

58. McDonagh M, Helfand M, Carson S, Russman BS: Hyperbaric oxygen therapy for traumatic brain injury: a systematic review of the evidence. Arch Phys Med Rehabil 2004, 85(7):1198-204.

59. Adamides AA, Winter CD, Lewis PM, Cooper DJ, Kossmann T, Rosenfeld JV: Current controversies in the management of patients with severe traumatic brain injury. ANZ J Surg 2006, 76(3):163-74.

60. Alternative Therapy Evaluation Committee for the Insurance Corporation of British Columbia: A review of the scientific evidence on the treatment of traumatic brain injuries and strokes with hyperbaric oxygen. Brain Inj 2003, 17(3):225-36

61. Boerema I, Meyne NG, Brummelkamp WK, Bouma S, Mensch MH, Kamermans F, Sternhanf M, Van Aaldern W, Life without blood: A study of the influence of high atmospheric pressure and hypothermia on dilution of the blood. J Cardiovasc Surg 1960, 1:133-146.

62. Jacobson I, Lawson DD: Effect of hyperbaric oxygen on experimental cerebral infarction in dog with preliminary correlations of cerebral blood flow at 2 atmospheres of oxygen. J Neurosurg 1963, 20:849-59.

63. Yang ZJ, Xie Y, Bosco GM, Chen C, Camporesi EM: Hyperbaric oxygenation alleviates MCAO-induced brain injury and reduces hydroxyl radical formation and glutamate release. Eur J Appl Physiol 2010, 108(3):513-22. 
64. Michalski D, Küppers-Tiedt L, Weise C, Laignel F, Härtig W, Raviolo M, Schneider D, Hobohm C: Long-term functional and neurological outcome after simultaneous treatment with tissue-plasminogen activator and hyperbaric oxygen in early phase of embolic stroke in rats. Brain Res 2009, 1303:161-8.

65. Hou H, Grinberg $\mathrm{O}$, Williams B, Grinberg $\mathrm{S}, \mathrm{Yu} H$, Alvarenga DL, Wallach $H$, Buckey J, Swartz HM: The effect of oxygen therapy on brain damage and cerebral $\mathrm{pO}_{2}$ in transient focal cerebral ischemia in the rat. Physiol Meas 2007, 28(8):963-76.

66. Veltkamp R, Siebing DA, Heiland S, Schoenffeldt-Varas P, Veltkamp C, Schwaninger $M$, Schwab S: Hyperbaric oxygen induces rapid protection against focal cerebral ischemia. Brain Res 2005, 1037(1-2):134-8.

67. Yin D, Zhang $\mathrm{JH}$ : Delayed and multiple hyperbaric oxygen treatments expand therapeutic window in rat focal cerebral ischemic model. Neurocrit Care 2005, 2(2):206-11.

68. Lebedev W, Isakov lu V, Pravdenkova SV: [Effect of hyperbaric oxygenation on the clinical course and complications of the acute period of ischemic strokes]. Zh Vopr Neirokhir Im N N Burdenko 1983, , 3: 37-42.

69. Pravdenkova SV, Romasenko MV, Shelkovskii VN: [Hyperbaric oxygenation and prevention of recurrent cerebral circulatory disorders in the acute stage of a stroke]. Zh Nevropatol Psikhiatr Im S S Korsakova 1984, 84(8):1147-51.

70. Holbach KH, Wassman $H$, Kolberg T: Verbesserte reversibilita"t des traumatischen mittelhirnsyndroms bei Anwendung der hyperbaren oxygenierung. Acta Neurochir 1974, 30:247-56.

71. Wassmann $\mathrm{H}$ : [Stroke therapy. Combined therapy of hyperbaric oxygenation and extra-intracranial arterial bypass operation]. Fortschr Med 1982, 100(7):285-8.

72. Anderson DC, Bottini AG, Jagiella WM, Westphal B, Ford S, Rockswold GL, Loewenson RB: A pilot study of hyperbaric oxygen in the treatment of human stroke. Stroke 1991, 22(9):1137-42

73. Nighoghossian N, Trouillas P, Adeleine P, Salord F: Hyperbaric oxygen in the treatment of acute ischemic stroke. A double-blind pilot study. Stroke 1995, 26(8):1369-72.

74. Rusyniak DE, Kirk MA, May JD, Kao LW, Brizendine EJ, Welch JL, Cordell WH, Alonso RJ, Hyperbaric oxygen therapy in acute ischemic stroke: Hyperbaric oxygen therapy in acute ischemic stroke: Results of the hyperbaric oxygen in acute ischemic stroke trial pilot study. Stroke 2003, 34(2):571-4.

75. Bennett MH, Wasiak J, Schnabel A, Kranke P, French C: Hyperbaric oxygen therapy for acute ischemic stroke. Cochrane Database Syst Rev 2005, , 3 : CD004954.

76. Dahl NA, Balfour WM: Prolonged anoxic survival due to anoxia preexposure: brain ATP, lactate, and pyruvate. Am J Physiol 1964, 207:452-6.

77. Schurr A, Reid KH, Tseng MT, West C, Rigor BM: Adaptation of adult brain tissue to anoxia and hypoxia in vitro. Brain Res 1986, 374(2):244-8.

78. Geft IL, Fishbein MC, Ninomiya K, Hashida J, Chaux E, Yano J, Y-Rit J, Genov T, Shell W, Ganz W: Intermittent brief periods of ischemia have a cumulative effect and may cause myocardial necrosis. Circulation 1982, 66(6):1150-3

79. Murry $C E$, Jennings RB, Reimer KA: Preconditioning with ischemia: a delay of lethal cell injury in ischemic myocardium. Circulation Circulation 1986, 74(5):1124-36.

80. Kitagawa K, Matsumoto M, Kuwabara K, Tagaya M, Ohtsuki T, Hata R, Ueda H, Handa N, Kimura K, Kamada T: 'Ischemic tolerance' phenomenon detected in various brain regions. Brain Res 1991, 561(2):203-11.

81. Chevion M, Leibowitz S, Aye NN, Novogrodsky O, Singer A, Avizemer O, Bulvik B, Konijn AM, Berenshtein E: Heart protection by ischemic preconditioning: a novel pathway initiated by iron and mediated by ferritin. J Mol Cell Cardiol 2008, 45(6):839-45

82. Rehni AK, Singh TG, Behl N, Arora S: Possible involvement of ubiquitin proteasome system and other proteases in acute and delayed aspects of ischemic preconditioning of brain in mice. Biol Pharm Bull 2010, 33(12):1953-7.

83. Xia ZY, Gao J, Ancharaz AK: Protective effect of ischemic postconditioning on lung ischemia-reperfusion injury in rats and the role of heme oxygenase-1. Chin J Traumatol 2009, 12(3):162-6.

84. Cho WY, Choi HM, Lee SY, Kim MG, Kim HK, Jo SK: The role of Tregs and $\mathrm{CD11c}(+)$ macrophages/dendritic cells ischemic preconditioning of the kidney. Kidney Int 2010, 78(10):981-92.
85. Romanque P, Díaz A, Tapia G, Uribe-Echevarría S, Videla LA, Fernandez V: Delayed ischemic preconditioning protects against liver ischemiareperfusion injury in vivo. Transplant Proc 2010, 42(5):1569-75.

86. Martin WJ, Howard DM: Paraquat-induced neutrophil alveolitis: reduction of the inflammatory response by pretreatment with endotoxin and hyperoxia. Lung 1986, 164(2):107-20.

87. D'Brot J, Ahmed T: Hyperoxia prevents hypoxia-induced bronchial hyperreactivity via a cyclooxygenase-independent mechanism. J Appl Physiol 1991, 70(2):740-7.

88. Wada K, Ito M, Miyazawa T, Katoh H, Nawashro H, Shima K, Chigasaki H: Repeated hyperbaric oxygen induces ischemic tolerance in gerbil hippocampus. Brain Res 1996, 740(1-2):15-20, 18

89. Qin Z, Hua Y, Liu W, Silbergleit R, He Y, Keep RF, Hoff JT, Xi G: Hyperbaric oxygen preconditioning activates ribosomal protein $\mathrm{S} 6$ kinases and reduces brain swelling after intracerebral hemorrhage. Acta Neurochir Supp/ 2008, 102:317-20.

90. Vince RV, Midgley AW, Laden G, Madden LA: The effect of hyperbaric oxygen preconditioning on heat shock protein 72 expression following in vitro stress in human monocytes. Cell Stress Chaperones 2011, 16(3):339-43.

91. Zhang $X$, Xiong L, Hu W, Zheng Y, Zhu Z, Liu Y, Chen S, Wang X: Preconditioning with prolonged oxygen exposure induces ischemic tolerance in the brain via oxygen free radical formation. Can J Anaesth 2004, 51(3):258-63.

92. Rasoulian B, Jafari M, Mahbod M, Dehaj ME, Nowrozi M, Wahhabaghai $H$, Mofid M, Ghasemi A, Bigdeli MR, Khoshbaten A: Pretreatment with oxygen protects rat kidney from cisplatin nephrotoxicity. Ren Fail 2010, 32(2):234-42.

93. Li J, Liu W, Ding S, Xu W, Guan Y, Zhang JH, Sun X: Hyperbaric oxygen preconditioning induces tolerance against brain ischemia-reperfusion injury by upregulation of antioxidant enzymes in rats. Brain Res 2008, 1210:223-9.

94. Nie H, Xiong L, Lao N, Chen S, Xu N, Zhu Z: Hyperbaric oxygen preconditioning induces tolerance against spinal cord ischemia by upregulation of antioxidant enzymes in rabbits. J Cereb Blood Flow Metab 2006, 26(5):666-74.

95. Koca K, Yurttas Y, Bilgic S, Cayci T, Topal T, Durusu M, Kaldirim U, Akgul EO, Ozkan H, Yanmis I, Oguz E, Tunay S, Korkmaz A, Basbozkurt M: Effect of preconditioned hyperbaric oxygen and ozone on ischemiareperfusion induced tourniquet in skeletal bone of rats. J Surg Res 2010, 164(1):e83-9.

96. Wahhabaghai H, Rasoulian B, Esmaili M, Mehrani HA, Mohammadhosseniakbari H, Mofid M, Jafari M, Noroozi M, Foadoddini M, Asgai A, Khoshbaten A: Hyperoxia-induced protection against rat's renal ischemic damage: relation to oxygen exposure time. Ren Fail 2009, 31(6):514-21.

97. Bigdeli MR: Preconditioning with prolonged normobaric hyperoxia induces ischemic tolerance partly by upregulation of antioxidant enzymes in rat brain tissue. Brain Res 2009, 1260:47-54.

98. Bigdeli MR, Rasoulian B, Meratan AA: In vivo normobaric hyperoxia preconditioning induces different degrees of antioxidant enzymes activities in rat brain tissue. Eur J Pharmacol 2009, 611(1-3):22-9.

99. Peng Z, Ren P, Kang Z, Du J, Lian Q, Liu Y, Zhang JH, Sun X: Up-regulated HIF-1alpha is involved in the hypoxic tolerance induced by hyperbaric oxygen preconditioning. Brain Res 2008, 1212:71-8.

100. Gu GJ, Li YP, Peng ZY, Xu JJ, Kang ZM, Xu WG, Tao HY, Ostrowski RP, Zhang $\mathrm{JH}$, Sun $\mathrm{XJ}$ : Mechanism of ischemic tolerance induced by hyperbaric oxygen preconditioning involves upregulation of hypoxiainducible factor-1a and erythropoietin in rats. J Appl Physiol 2008, 104(4):1185-91.

101. Ren P, Kang Z, Gu G, Liu Y, Xu W, Tao H, Zhang JH, Sun X, Ji H: Hyperbaric oxygen preconditioning promotes angiogenesis in rat liver after partial hepatectomy. Life Sci 2008, 83(7-8):236-41.

102. Jadhav V, Ostrowski RP, Tong W, Matus B, Jesunathadas R, Zhang JH: Cyclooxygenase- 2 mediates hyperbaric oxygen preconditioning-induced neuroprotection in the mouse model of surgical brain injury. Stroke 2009, 40(9):3139-42.

103. Cheng O, Ostrowski RP, Wu B, Liu W, Chen C, Zhang JH: Cyclooxygenase-2 Mediates Hyperbaric Oxygen Preconditioning in the Rat Model of Transient Global Cerebral Ischemia. Stroke 2011, 42(2):484-90. 
104. Liu W, Li J, Sun X, Liu K, Zhang JH, Xu W, Tao H: Repetitive hyperbaric oxygen exposures enhance sensitivity to convulsion by upregulation of eNOS and nNOS. Brain Res 2008, 1201:128-34

105. Ostrowski RP, Jadhav V, Chen W, Zhang JH: Reduced matrix metalloproteinase- 9 activity and cell death after global ischemia in the brain preconditioned with hyperbaric oxygen. Acta Neurochir Supp/ 2010 106:47-9.

106. Ostrowski RP, Graupner G, Titova E, Zhang J, Chiu J, Dach N, Corleone D, Tang J, Zhang JH: The hyperbaric oxygen preconditioning-induced brain protection is mediated by a reduction of early apoptosis after transient global cerebral ischemia. Neurobiol Dis 2008, 29(1):1-13.

107. Yamashita S, Hirata T, Mizukami Y, Cui YJ, Fukuda S, Ishida K, Matsumoto M, Sakabe T: Repeated preconditioning with hyperbaric oxygen induces neuroprotection against forebrain ischemia via suppression of p38 mitogen activated protein kinase. Brain Res 2009, 1301:171-9.

108. Ruusalepp A, Czibik G, Flatebø T, Vaage J, Valen G: Myocardial protection evoked by hyperoxic exposure involves signaling through nitric oxide and mitogen activated protein kinases. Basic Res Cardiol 2007, 102(4):318-26.

109. Nakamura K, Martin KC, Jackson JK, Beppu K, Woo CW, Thiele CJ: Brain derived neurotrophic factor activation of Trk $B$ induces vascular endothelial growth factor expression via hypoxia inducible factor-1a in neuroblastoma cells. Cancer Res 2006, 66(8):4249-55.

110. Li JS, Zhang W, Kang ZM, Ding SJ, Liu WW, Zhang JH, Guan YT, Sun XJ: Hyperbaric oxygen preconditioning reduces ischemia-reperfusion injury by inhibition of apoptosis via mitochondrial pathway in rat brain. Neuroscience 2009, 159(4):1309-15.

111. Li Z, Liu W, Kang Z, Lv S, Han C, Yun L, Sun X, Zhang JH: Mechanism of hyperbaric oxygen preconditioning in neonatal hypoxia-ischemia rat model. Brain Res 2008, 1196:151-6.

112. Petrosillo G, Di Venosa N, Moro N, Colantuono G, Paradies V, Tiravanti E, Federici A, Ruggiero FM, Paradies G: In vivo hyperoxic preconditioning protects against rat-heart ischemia/reperfusion injury by inhibiting mitochondrial permeability transition pore opening and cytochrome $\mathrm{c}$ release. Free Radic Biol Med 2011, 50(3):477-83.

113. Bigdeli MR, Rahnema M, Khoshbaten A: Preconditioning with subletha ischemia or intermittent normobaric hyperoxia up-regulates glutamate transporters and tumor necrosis factor-alpha converting enzyme in the rat brain. J Stroke Cerebrovasc Dis 2009, 18(5):336-42

114. Colantuono G, Tiravanti EA, Di Venosa N, Cazzato A, Rastaldo R, Cagiano R, D'Agostino D, Federici A, Fiore T: Hyperoxia confers myocardial protection in mechanically ventilated rats through the generation of free radicals and opening of mitochondrial ATP-sensitive potassium channels. Clin Exp Pharmacol Physiol 2008, 35(1):64-71.

115. Labruto F, Yang J, Vaage J, Valen G: Role of tumor necrosis factor alpha and its receptor I in preconditioning by hyperoxia. Basic Res Cardiol 2005, 100(3):198-207.

116. Tähepõld P, Vaage J, Starkopf J, Valen G: Hyperoxia elicits myocardial protection through a nuclear factor kappaB-dependent mechanism in the rat heart. J Thorac Cardiovasc Surg 2003, 125(3):650-60.

117. Hirata T, Cui YJ, Funakoshi T, Mizukami Y, Ishikawa Y, Shibasaki F, Matsumoto M, Sakabe T: The temporal profile of genomic responses and protein synthesis in ischemic tolerance of the rat brain induced by repeated hyperbaric oxygen. Brain Res 2007, 1130(1):214-22.

118. Wang L, Li W, Kang Z, Liu Y, Deng X, Tao H, Xu W, Li R, Sun X, Zhang JH: Hyperbaric oxygen preconditioning attenuates early apoptosis after spinal cord ischemia in rats. J Neurotrauma 2009, 26(1):55-66.

119. Jenkinsons S: Oxygen toxicity. New Horizons 1993, 1(4):504-11.

120. Smerz R: Incidence of oxygen toxicity events during the treatment of dysbarism. Undersea Hyperb Med 2004, 31(2):199-202.

121. Weinberger $B$, Laskin $D L$, Heck DE, Laskin JD: Oxygen toxicity in premature infants. Toxicol Appl Pharmacol 2002, 181(1):60-7.

122. Berg JT, Furusawa E: Failure of juice or juice extract from the noni plant (Morinda citrifolia) to protect rats against oxygen toxicity. Hawaii Med J 2007, 66(2):41-4

123. Arieli R: Heliox, nitrox, and trimix diving; hyperbaric oxygen treatment; and a flaw in Henry's law. J Appl Physiol 2007, 102(4):1323

124. Hyldegaard O, Jensen T: Effect of heliox, oxygen and air breathing on helium bubbles after heliox diving. Undersea Hyperb Med 2007, 34(2):107-22.
125. Barach AL: Use of helium as a new therapeutic gas. Proc Soc Exp Bio Med 1934, 32:462-4

126. Barach AL: The therapeutic use of helium. JAMA 1935, 107:1273-80.

127. Kress JP, Noth I, Gehlbach BK, Barman N, Pohlman AS, Miller A, Morgan S, Hall JB: The utility of albuterol nebulized with heliox during acute asthma exacerbations. Am J Respir Crit Care Med 2002, 165(9):1317-21.

128. Martinón-Torres F, Rodríguez-Núñez A, Martinón-Sánchez JM: Heliox therapy in infants with acute bronchiolitis. Pediatrics 2002, 109(1):68-73.

129. Eves ND, Sandmeyer LC, Wong EY, Jones LW, MacDonald GF, Ford GT, Petersen SR, Bibeau MD, Jones RL: Helium-hyperoxia: a novel intervention to improve the benefits of pulmonary rehabilitation for patients with COPD. Chest 2009, 135(3):609-18.

130. Kudukis TM, Manthous CA, Schmidt GA, Hall JB, Wylam ME: Inhaled heliumoxygen revisited: effect of inhaled helium-oxygen during the treatment of status asthmaticus in children. J Pediatr 1997, 130(2):217-24

131. Winkelmann J: Gases in gases, liquids and their mixtures. Data extract from Landolt-Börnstein IV/15A, Chapter 4.1.1: Diffusion in Binary Gaseous Mixtures. Landolt-Börnstein-Group IV Physical Chemistry. Springer Berlin Heidelberg 2007, 15A:1615-2018.

132. Pifarré R, Raghunath TK, Vanecko RM, Chua FS, Balis JU, Neville WE: Effect of oxygen and helium mixtures on ventricular fibrillation. J Thorac Cardiovasc Surg 1970, 60(5):648-52.

133. Nie M, Kobayashi H, Sugawara M, Tomita T, Ohara K, Yoshimura H: Helium inhalation enhances vasodilator effect of inhaled nitric oxide on pulmonary vessels in hypoxic dogs. Am J Physiol: Heart Circ Physiol 2001, 280(4):H1875-81.

134. Debiński W, Kłossowski M, Gembicka D: Effect of breathing of a heliumoxygen mixture on the adaptation of the organism to exercise. Acta Physiol Pol 1984, 35(3):285-92.

135. Pagel PS, Krolikowski JG, Shim YH, Venkatapuram S, Kersten JR, Weihrauch D, Warltier DC, Pratt PF Jr: Noble gases without anesthetic properties protect myocardium against infarction by activating prosurvival signaling kinases and inhibiting mitochondrial permeability transition in vivo. Anesth Analg 2007, 105(3):562-9.

136. Heinen A, Huhn R, Smeele KM, Zuurbier CJ, Schlack W, Preckel B, Weber NC, Hollmann MW: Helium-induced preconditioning in young and old rat heart: impact of mitochondrial $\mathrm{Ca}^{2+}$-sensitive potassium channel activation. Anesthesiology 2008, 109(5):830-6.

137. Pagel PS, Krolikowski JG, Pratt PF Jr, Shim YH, Amour J, Warltier DC, Weihrauch D: Reactive oxygen species and mitochondrial adenosine triphosphate-regulated potassium channels mediate helium-induced preconditioning against myocardial infarction in vivo. J Cardiothorac Vasc Anesth 2008, 22(4):554-9.

138. Pagel PS, Krolikowski JG, Pratt PF Jr, Shim YH, Amour J, Warltier DC, Weihrauch D: The mechanism of helium-induced preconditioning: a direct role for nitric oxide in rabbits. Anesth Analg 2008, 107(3):762-8.

139. Pagel PS, Krolikowski JG, Pratt PF Jr, Shim YH, Amour J, Warltier DC, Weihrauch D: Inhibition of glycogen synthase kinase or the apoptotic protein p53 lowers the threshold of helium cardioprotection in vivo: the role of mitochondrial permeability transition. Anesth Analg 2008, 107(3):769-75.

140. Pagel PS, Krolikowski JG, Amour J, Warltier DC, Weihrauch D: Morphine reduces the threshold of helium preconditioning against myocardial infarction: the role of opioid receptors in rabbits. J Cardiothorac Vasc Anesth 2009, 23(5):619-24.

141. Lucchinetti E, Wacker J, Maurer C, Keel M, Härter L, Zaugg K, Zaugg M: Helium breathing provides modest anti-inflammatory, but no endothelial protection against ischemia-reperfusion injury in humans in vivo. Anesth Analg 2009, 109(1):101-8.

142. Pan Y, Zhang H, VanDeripe DR, Cruz-Flores S, Panneton WM: Heliox and oxygen reduce infarct volume in a rat model of focal ischemia. Exp Neurol 2007, 205(2):587-90

143. Jawad N, Rizvi M, Gu J, Adeyi O, Tao G, Maze M, Ma D: Neuroprotection (and lack of neuroprotection) afforded by a series of noble gases in an in vitro model of neuronal injury. Neurosci Lett 2009, 460(3):232-6.

144. Rizvi M, Jawad N, Li Y, Vizcaychipi MP, Maze M, Ma D: Effect of noble gases on oxygen and glucose deprived injury in human tubular kidney cells. Exp Biol Med (Maywood) 2010, 235(7):886-91.

145. Franks NP, Dickinson R, De Sousa SL, Hall AC, Lieb WR: How does xenon produce anaesthesia? Nature. 1998, 396:324. 
146. Banks P, Franks NP, Dickinson R: Competitive inhibition at the glycine site of the N-methyl-D-aspartate receptor mediates xenon neuroprotection against hypoxia-ischemia. Anesthesiology 2010, 112(3):614-22.

147. Plested AJR, Wildman SS, Lieb WR, Franks NP: Determinants of the sensitivity of AMPA receptors to xenon. Anesthesiology 2004, 100(2):347-58.

148. Yamakura T, Harris RA: Effects of gaseous anesthetics nitrous oxide and xenon on ligand-gated ion channels: Comparison with isoflurane and ethanol. Anesthesiology 2000, 93(4):1095-101.

149. Suzuki T, Koyama H, Sugimoto M, Uchida I, Masimo T: The diverse actions of volatile and gaseous anesthetics on human-cloned 5hydroxytryptamine 3 receptors expressed in Xenopus oocytes. Anesthesiology 2002, 96(3):699-704.

150. Bantel C, Maze M, Trapp S: Noble gas xenon is a novel adenosine triphosphate-sensitive potassium channel opener. Anesthesiology 2010, 112(3):623-30.

151. Gruss M, Bushell TJ, Bright DP, Lieb WR, Mathie A, Franks NP: Twoporedomain $\mathrm{K}^{+}$channels are a novel target for the anesthetic gases xenon, nitrous oxide, and cyclopropane. Mol Pharmacol 2004, 65:443-52.

152. Shichino T, Murakawa M, Adachi T, Miyazaki $Y$, Segawa H, Fukuda K, Mori K: Effects of xenon on acetylcholine release in the rat cerebral cortex in vivo. Br J Anaesth 2002, 88(6):866-8.

153. Ishiguro $Y$, Kikuchi T, Etsuki H, Niimi Y, Goto T, Morita S, Irie T: Does xenon anesthesia inhibit cholinesterase? An in vitro radiometric assessment. Anesthesiology 2003, 98(3):791-2.

154. Galley HF, Le Cras AE, Logan SD, Webster NR: Differential nitric oxide synthase activity, cofactor availability and cGMP accumulation in the central nervous system during anaesthesia. Br J Anaesth 2001, 86(3):388-94.

155. Petzelt C, Ose's-Prieto J, Klett FF, Schmehl W, Kox WJ: Effects of xenon on intracellular $\mathrm{Ca}^{2+}$ release in human endothelial cells. Exp Biol Online 1997, 2:3-9.

156. Franks JJ, Horn J-L, Janicki PK, Singh G: Halothane, isoflurane, xenon, and nitrous oxide inhibit calcium ATPase pump activity in rat brain synaptic plasma membranes. Anesthesiology 1995, 82(1):108-17.

157. Laitio RM, Kaisti KK, Låangsjö JW, Aalto S, Salmi E, Maksimow A, Aantaa R, Oikonen V, Sipilä H, Parkkola R, Scheinin H: Effects of xenon anesthesia on cerebral blood flow in humans: a positron emission tomography study. Anesthesiology 2007, 106(6):1128-33.

158. Rex S, Schaefer W, Meyer PH, Rossaint R, Boy C, Setani K, Büll U, Baumert JH: Positron emission tomography study of regional cerebral metabolism during general anesthesia with xenon in humans. Anesthesiology 2006, 105(5):936-43.

159. Weber NC, Toma O, Wolter J, Obal D, Mullenheim J, Preckel B, Schlack W: The noble gas xenon induces pharmacological preconditioning in the rat heart in vivo via induction of PKC $-\varepsilon$ and p38 MAPK. Br J Pharmacol 2005, 144(1):123-32.

160. Weber NC, Toma O, Damla H, Wolter Jl, Schlack W, Preckel B: Upstream signaling of protein kinase $C-\varepsilon$ in xenon-induced pharmacological preconditioning. Implication of mitochondrial adenosine triphosphate dependent potassium channels and phosphatidylinositol-dependent kinase-1. Eur J Pharmacol 2006, 539(1-2):1-9.

161. Weber NC, Toma O, Wolter J, Wirthle NM, Schlack W, Preckel B: Mechanisms of xenon-and isoflurane-induced preconditioning-a potential link to the cytoskeleton via the MAPKAPK-2/HSP27 pathway. $\mathrm{Br}$ J Pharmacol 2005, 146(3):445-55.

162. Weber NC, Stursberg J, Wirthle NM, Toma O, Schlack W, Preckel B: Xenon preconditioning differently regulates $\mathrm{p} 44 / 42$ MAPK (ERK 1/2) and p46/54 MAPK (JNK 1/2 and 3) in vivo. Br J Anaesth 2006, 97(3):298-306.

163. Mio Y, Shim YH, Richards E, Bosnjak ZJ, Pagel PS, Bienengraeber M: Xenon preconditioning: the role of prosurvival signaling, mitochondrial permeability transition and bioenergetics in rats. Anesth Analg 2009, 108(3):858-66

164. Ma D, Williamson $P$, Januszewski $A$, Nogaro MC, Hossain M, Ong LP, Shu $Y$, Franks NP, Maze M: Xenon mitigates isoflurane-induced neuronal apoptosis in the developing rodent brain. Anesthesiology 2007, 106(4):746-53.

165. Shu Y, Patel SM, Pac-Soo C, Fidalgo AR, Wan Y, Maze M, Ma D: Xenon pretreatment attenuates anesthetic-induced apoptosis in the developing brain in comparison with nitrous oxide and hypoxia. Anesthesiology 2010, 113(2):360-8.
166. de Rossi LW, Horn NA, Stevanovic A, Buhre W, Hutschenreuter G, Rossaint R: Xenon modulates neutrophil adhesion molecule expression in vitro. Eur J Anaesthesiol 2004, 21(2):139-43.

167. Weber NC, Frässdorf J, Ratajczak C, Grueber Y, Schlack W, Hollmann MW, Preckel $B$ : Xenon induces late cardiac preconditioning in vivo: a role for cyclooxygenase 2? Anesth Analg 2008, 107(6):1807-13.

168. Sanders RD, Franks NP, Maze M: Xenon. No stranger to anaesthesia. $\mathrm{Br} J$ Anaesth 2003, 91(5):709-17.

169. Ma D, Wilhelm S, Maze M, Franks NP: Neuroprotective and neurotoxic properties of the inert gas xenon. Br J Anaesth 2002, 89(5):739-46.

170. Wilhelm S, Ma D, Maze M, Franks NP: Effects of xenon on in vitro and in vivo models of neuronal injury. Anesthesiology 2002, 96(6):1485-91.

171. Petzelt C, Blom P, Schmehl W, Müller J, Kox WJ: Prevention of neurotoxicity in hypoxic cortical neurons by the noble gas xenon. Life Sci 2003, 72(17):1909-18

172. Petzelt C, Blom P, Schmehl W, Müller J, Kox WJ: Xenon prevents cellular damage in differentiated PC-12 cells exposed to hypoxia. BMC Neurosci 2004, 5:55.

173. Homi HM, Yokoo N, Ma D, Warner DS, Franks NP, Maze M, Grocott HP: The neuroprotective effect of xenon administration during transient middle cerebral artery occlusion in mice. Anesthesiology 2003, 99(4):876-81.

174. Dingley J, Tooley J, Porter H, Thoresen M: Xenon provides short-term neuroprotection in neonatal rats when administered after hypoxiaischemia. Stroke 2006, 37(2):501-6.

175. David HN, Haelewyn B, Rouillon C, Lecoq M, Chazalviel L, Apiou G, Risso JJ, Lemaire $M$, Abraini $J \mathrm{H}$ : Neuroprotective effects of xenon: a therapeutic window of opportunity in rats subjected to transient cerebral ischemia. FASEB J 2008, 22(4):1275-86.

176. Natale G, Cattano D, Abramo A, Forfori F, Fulceri F, Fornai F, Paparelli A Giunta F: Morphological evidence that xenon neuroprotects against Nmethyl-DL-aspartic acid-induced damage in the rat arcuate nucleus: a time-dependent study. Ann N Y Acad Sci 2006, 1074:650-8,

177. Ma D, Hossain M, Chow A, Arshad M, Battson RM, Sanders RD, Mehmet $H_{\text {, }}$ Edwards AD, Franks NP, Maze M: Xenon and hypothermia combine to provide neuroprotection from neonatal asphyxia. Ann Neurol 2005, 58(2):182-93.

178. Rajakumaraswamy N, Ma D, Hossain M, Sanders RD, Franks NP, Maze M: Neuroprotective interaction produced by xenon and dexmedetomidine on in vitro and in vivo neuronal injury models. Neurosci Lett 2006 409(2):128-33

179. Ma D, Hossain M, Pettet GK, Luo Y, Lim T, Akimov S, Sanders RD, Franks NP, Maze $M$ : Xenon preconditioning reduces brain damage from neonatal asphyxia in rats. J Cereb Blood Flow Metab 2006, 26(2):199-208.

180. Luo Y, Ma D, leong E, Sanders RD, Yu B, Hossain M, Maze M: Xenon and sevoflurane protect against brain injury in a neonatal asphyxia model. Anesthesiology 2008, 109(5):782-9.

181. Christl SU, Murgatroyd PR, Gibson GR, Cummings JH: Production, metabolism, and excretion of hydrogen in the large intestine. Gastroenterology 1992, 102(4 Pt 1):1269-77.

182. Hammer HF: Colonic hydrogen absorption: quantification of its effect on hydrogen accumulation caused by bacterial fermentation of carbohydrates. Gut 1993, 34(6):818-22.

183. Maier RJ: Use of molecular hydrogen as an energy substrate by human pathogenic bacteria. Biochem Soc Trans 2005, 33(Pt 1):83-5.

184. Rumessen JJ: Hydrogen and methane breath tests for evaluation of resistant carbohydrates. Eur J Clin Nutr 1992, 46(Suppl 2):S77-90.

185. Di Camillo M, Marinaro V, Argnani F, Foglietta T, Vernia P: Hydrogen breath test for diagnosis of lactose malabsorption: the importance of timing and the number of breath samples. Can J Gastroenterol 2006, 20(4):265-268

186. Schneider AR, Jepp K, Murczynski L, Biniek U, Stein J: The inulin hydrogen breath test accurately reflects orocaecal transit time. Eur J Clin Invest 2007, 37(10):802-7.

187. Dole M, Wilson FR, Fife WP: Hyperbaric hydrogen therapy: a possible treatment for cancer. Science 1975, 190(4210):152-4

188. Kayar SR, Axley MJ, Homer LD, Harabin AL: Hydrogen gas is not oxidized by mammalian tissues under hyperbaric conditions. Undersea Hyperb Med 1994, 21(3):265-75.

189. Gharib B, Hanna S, Abdallahi OM, Lepidi H, Gardette B, De Reggi M: Antiinflammatory properties of molecular hydrogen: investigation on parasite-induced liver inflammation. C R Acad Sci III 2001, 324(8):719-24. 
190. Ohsawa I, Ishikawa M, Takahashi K, Watanabe M, Nishimaki K, Yamagata K, Katsura K, Katayama Y, Asoh S, Ohta S: Hydrogen acts as a therapeutic antioxidant by selectively reducing cytotoxic oxygen radicals. Nat Med 2007, 13(6):688-94.

191. Kajiyama S, Hasegawa G, Asano M, Hosoda H, Fukui M, Nakamura N, Kitawaki J, Imai S, Nakano K, Ohta M, Adachi T, Obayashi H, Yoshikawa T: Supplementation of hydrogen-rich water improves lipid and glucose metabolism in patients with type 2 diabetes or impaired glucose tolerance. Nutr Res 2008, 28(3):137-43.

192. Xie K, Yu Y, Pei Y, Hou L, Chen S, Xiong L, Wang G: Protective effects of hydrogen gas on murine polymicrobial sepsis via reducing oxidative stress and HMGB1 release. Shock 2010, 34(1):90-7.

193. Sun Q, Kang Z, Cai J, Liu W, Liu Y, Zhang JH, Denoble PJ, Tao H, Sun X: Hydrogen-rich saline protects myocardium against ischemia/reperfusion injury in rats. Exp Biol Med (Maywood) 2009, 234(10):1212-9.

194. Cai J, Kang Z, Liu WW, Luo X, Qiang S, Zhang JH, Ohta S, Sun X, Xu W, Tao H, Li R: Hydrogen therapy reduces apoptosis in neonatal hypoxiaischemia rat model. Neurosci Lett 2008, 441:167-172

195. Cai J, Kang Z, Liu K, Liu W, Li R, Zhang JH, Luo X, Sun X: Neuroprotective effects of hydrogen saline in neonatal hypoxia-ischemia rat model. Brain Res 2009, 1256:129-137.

196. Matchett GA, Fathali N, Hasegawa Y, Jadhav V, Ostrowski RP, Martin RD, Dorotta IR, Sun X, Zhang JH: Hydrogen gas is ineffective in moderate and severe neonatal hypoxia-ischemia rat models. Brain Res 2009, 1259:90-97.

197. Sato Y, Kajiyama S, Amano A, Kondo Y, Sasaki T, Handa S, Takahashi R, Fukui M, Hasegawa G, Nakamura N, Fujinawa H, Mori T, Ohta M, Obayashi H, Maruyama N, Ishigami A: Hydrogen-rich pure water prevents superoxide formation in brain slices of vitamin C-depleted SMP30/GNL knockout mice. Biochem Biophys Res Commun 2008, 375:346-350.

198. Li J, Wang C, Zhang JH, Cai JM, Cao YP, Sun XJ: Hydrogen rich saline improves memory function in a rat model of amyloid-beta-induced Alzheimer's disease by reduction of oxidative stress. Brain Res 2010, 1328:152-61

199. Chen CH, Manaenko A, Zhan Y, Liu WW, Ostrowki RP, Tang J, Zhang JH: Hydrogen gas reduced acute hyperglycemia-enhanced hemorrhagic transformation in a focal ischemia rat model. Neuroscience 2010, 169(1):402-14.

200. Nagata K, Nakashima-Kamimura N, Mikami T, Ohsawa I, Ohta S: Consumption of molecular hydrogen prevents the stress-induced impairments in hippocampus-dependent learning tasks during chronic physical restraint in mice. Neuropsychopharmacol 2009, 34:501-508.

201. Fujita K, Seike T, Yutsudo N, Ohno M, Yamada H, Yamaguchi H, Sakumi K, Yamakawa Y, Kido MA, Takaki A, Katafuchi T, Tanaka Y, Nakabeppu Y, Noda M: Hydrogen in drinking water reduces dopaminergic neuronal loss in the 1-methyl-4-phenyl-1,2,3,6-tetrahydropyridine mouse model of Parkinson's disease. PLoS One 2009, 4:e7247.

202. Fu Y, Ito M, Fujita Y, Ichihara M, Masuda A, Suzuki Y, Maesawa S, Kajita Y, Hirayama M, Ohsawa I, Ohta S, Ohno K: Molecular hydrogen is protective against 6-hydroxydopamine-induced nigrostriatal degeneration in a rat model of Parkinson's disease. Neurosci Lett 2009, 453(2):81-5.

203. Gu Y, Huang CS, Inoue T, Yamashita T, Ishida T, Kang KM, Nakao A: Drinking hydrogen water ameliorated cognitive impairment in senescence-accelerated mice. J Clin Biochem Nutr 2010, 46(3):269-76.

204. Ryang YM, Fahlenkamp AV, Rossaint R, Wesp D, Loetscher PD, Beyer C, Coburn M: Neuroprotective effects of argon in an in vivo model of transient middle cerebral artery occlusion in rats. Crit Care Med 2011.

205. Loetscher PD, Rossaint J, Rossaint R, Weis J, Fries M, Fahlenkamp A, Ryang YM, Grottke O, Coburn M: Argon: neuroprotection in in vitro models of cerebral ischemia and traumatic brain injury. Crit Care 2009, 13(6):R206.

206. Jawad N, Rizvi M, Gu J, Adeyi O, Tao G, Maze M, Ma D: Neuroprotection (and lack of neuroprotection) afforded by a series of noble gases in an in vitro model of neuronal injury. Neurosci Lett 2009, 460(3):232-6.

207. Limatola V, Ward P, Cattano D, Gu J, Giunta F, Maze M, Ma D: Xenon preconditioning confers neuroprotection regardless of gender in a mouse model of transient middle cerebral artery occlusion. Neuroscience 2010, 165(3):874-81.

208. Bantel C, Maze M, Trapp S: Neuronal preconditioning by inhalational anesthetics: evidence for the role of plasmalemmal adenosine triphosphate-sensitive potassium channels. Anesthesiology 2009, 110(5):986-95.
209. Domoki F, Oláh O, Zimmermann A, Németh I, Tóth-Szuki V, Hugyecz M, Temesvári P, Bari F: Hydrogen is neuroprotective and preserves cerebrovascular reactivity in asphyxiated newborn pigs. Pediatr Res 2010, 68(5):387-92.

doi:10.1186/2045-9912-1-13

Cite this article as: Liu et al:: Application of medical gases in the field of neurobiology. Medical Gas Research 2011 1:13.

\section{Submit your next manuscript to BioMed Central and take full advantage of:}

- Convenient online submission

- Thorough peer review

- No space constraints or color figure charges

- Immediate publication on acceptance

- Inclusion in PubMed, CAS, Scopus and Google Scholar

- Research which is freely available for redistribution

Submit your manuscript at www.biomedcentral.com/submit
Biomed Central 